\title{
THE MATURATION AND \\ DISINTEGRATION OF THE HEARSAY EXCEPTION FOR STATEMENTS FOR MEDICAL EXAMINATION IN CHILD SEXUAL ABUSE CASES
}

\author{
ROBERT P. MOSTELLER*
}

\section{INTRODUCTION}

The purpose of this symposium is to examine the treatment of children as victims and witnesses in criminal trials, most frequently involving sexual abuse, over the last quarter of the twentieth century and, from that experience, to draw lessons. In this essay, I examine what we have learned about the hearsay exception for "statements for purposes of medical diagnosis or treatment." Earlier, I studied this exception as applied in child sexual abuse prosecutions and found it being stretched beyond the bounds of its theoretical justification. ${ }^{2}$ In this essay, I reexamine our national experience with the exception over the past decade and find both a maturation of the exception and at least a partial disintegration.

Briefly, the hearsay exception admits statements made by a person for the purpose of either receiving treatment or allowing a doctor to diagnose without any expectation of treatment. ${ }^{3}$ The statements may concern the individual's present symptoms, medical history, or the general character of the condition or injury that prompted the medical visit. To be admissible, the statements must be "reasonably pertinent to diagnosis or treatment," apparently from the perspective of either the declarant or the medical expert. Although central to the exception, no definition of the term "medical" is provided in the rule itself or in

Copyright (C) 2002 by Robert P. Mosteller

This article is also available at http://www.law.duke.edu/journals/65LCPMosteller.

* Professor of Law, Duke University. B.A. 1970, University of North Carolina at Chapel Hill; J.D. 1975, Yale University; M.P.P. 1975, Harvard University. I wish to thank Lucy McGough, Jean Montoya, John Myers, and Andy Taslitz for their helpful comments on an earlier draft.

1. The exception is codified for the federal courts as Federal Rule of Evidence 803(4).

2. See generally Robert P. Mosteller, Child Sexual Abuse and Statements for the Purpose of Medical Diagnosis or Treatment, 67 N.C. L. REV. 257 (1989). This article has played a role in the exception's development. See, e.g., State v. Hinnant, 523 S.E.2d 663, 668 (N.C. 2000) (relying on the article in restricting the exception to the traditional rationale); State v. Barone, 852 S.W.2d 216, 220 (Tenn. 1993) (relying on the article in excluding psychological testimony from the exception).

3. The ways in which the enactment of Federal Rule of Evidence 803(4) changed existing law are described in more detail later. See infra text accompanying notes 41-59. 
the accompanying commentary. Finally, the availability or unavailability of the person who made the statement is irrelevant to admissibility.

The exception is applied in a relatively straightforward and uncontroversial manner in typical civil cases involving accidents, injuries, sickness, and treatment. Its use is far more debatable as applied in child sexual abuse cases when one of the key issues is whether a child's statements describing sexual abuse, particularly statements identifying the abuser, are admissible.

To illustrate how the use of the exception can, in my judgment, be very troubling, consider the following hypothetical case:

A four-year-old female child, in the care of a single mother and her current live-in boyfriend, is found by social workers to be malnourished and poorly clothed. She is also apparently emotionally withdrawn. A physical examination reveals irritation in the genital area that is suggestive of sexual abuse several days earlier, but could also be fully explained in other ways. When asked by the examining pediatrician about her genital area, the child responds with very little information and the best that can be determined is that "it hurt." Because of the conditions of her care, the child is temporarily taken from her mother's custody. While in emergency care, the child is interviewed several times by social workers trying to determine whether sexual abuse occurred. She provides no additional information that would suggest sexual abuse. The interviews are not recorded.

Investigators continue to suspect abuse because of an unproven but reported incident of sexual abuse of a child two years earlier by Buddy, the mother's live-in boyfriend. The child is sent to a pediatrician who works regularly with the Department of Social Services in detecting and treating sexual abuse. The doctor is briefed on all the information in the case and the suspicions regarding Buddy. He conducts no physical exam, because the symptoms are no longer present. Without any witness present or any recording made, and with very few notes, the doctor interviews the child. He reports that the child told him that "Buddy hurt her bottom with his pee pee," writing this quotation in his notes. The child never repeats a statement of this sort in later interviews.

Buddy is charged with child sexual abuse. The child is not called as a witness by the state; she is found incompetent to testify because she does not understand the oath. The trial judge rejects the defense's objection based on hearsay and Confrontation Clause grounds, and allows the pediatrician to testify to the child's statement to him under the "medical examination exception," the doctor explaining that the inquiry was pertinent to the child's placement in foster care, away from Buddy. On cross-examination, the doctor denies that he used leading questions in eliciting the information, and cites his extensive 
experience investigating such cases. The trial judge denies the defense's motion to dismiss the case on grounds of insufficient evidence and submits the case to the jury for its verdict.

These facts are realistic and troubling. The case's outcome is uncertain, and the truth of the charges against the defendant is largely dependent upon the memory, the unconscious preconceptions, and the motivation of the doctor as to how he conducted the inquiry. In most jurisdictions, the questions of interviewing procedure and conscious or unconscious investigatory motivation are irrelevant to the admissibility of the hearsay statement, and, if convicted, the defendant would have no clearly meritorious issues on appeal. ${ }^{4}$ The issues raised by the above hypothetical are at the center of this article.

This article's title reflects three conclusions. First, this hearsay exception has matured and become more nuanced and contexualized. Largely during the 1980s, prosecutors began applying the exception broadly in child sexual abuse cases, and even more expansive use appeared theoretically possible, though it has not been extended to its theoretical boundaries. For example, courts did not adopt a general practice under this exception of receiving statements when made to experts who simply diagnosed a psychological condition, such as posttraumatic stress disorder, associated with a sexual assault. ${ }^{5}$ While the exception developed to provide a relatively broad pathway for the admission of hearsay of

4. The exception allows admission of a statement that is "reasonably pertinent to [medical] diagnosis or treatment" and does impose constraints on the method of eliciting the information or the adversarial motivation of the questioner. Unlike Federal Rules of Evidence 803(6) and 803(8), Rule 803(4) does not authorize exclusion if "the sources of information or the method or circumstances of preparation indicate lack of trustworthiness." That limiting language in those other hearsay rules was added to address problems of motivation as illustrated by Palmer v. Hoffman, which concerned records made for litigation purposes. 318 U.S. 109 (1943). See FED. R. EvID. 803(6) advisory committee's note. Thus, Rule 803(4) provides no direct way to consider these factors in the admission analysis. Similarly, under the generally applicable Confrontation Clause analysis, if the statement is admitted under this "firmly rooted" hearsay exception, the Constitution imposes further trustworthiness requirements. See White v. Illinois, 502 U.S. 346, 356 n.8 (1992) (concluding that statements for medical diagnosis or treatment are "firmly rooted"). See also Ohio v. Roberts, 448 U.S. 56, 66 (1980). Cf. Idaho v. Wright, 497 U.S. 805, 818 (1990) (rejecting for constitutional trustworthiness analysis the dispositive weight placed by the state court on lack of procedural safeguards, which included use of leading questions and interviewers' preconceived idea of information that would be disclosed). Thus, satisfying the Confrontation Clause will not require attention to these factors.

5. See, e.g., State v. Lucero, 863 P.2d 1071 (N.M. 1993) (holding that the trial court committed plain error in receiving the testimony of a clinical psychologist who named the perpetrator as part of testimony regarding post-traumatic stress disorder). The type of analysis that would confirm my fears if generally applied is found in United States v. Madoch, but it is not reflective of any larger trend. $935 \mathrm{~F}$. Supp. 965 (N.D. Ill. 1996). In Madoch, the district court, in an in limine ruling, examined statements regarding physical abuse made by the defendant to her psychiatrist who diagnosed certain personality disorders that would be offered by the defense to negate specific intent. Id. The statements of the defendant were ruled admissible under Rule 803(4) by virtue of the Seventh Circuit's analysis in Gong $v$. Hirsch, 913 F.2d 1269, 1274 n.4 (7th Cir. 1990), that any information reasonably relied upon by an expert within the meaning of Federal Rule of Evidence 703 is admissible under Rule 803(4) if relied on to form a medical diagnosis. Madoch, 935 F. Supp. at 972-74. Because Madoch involved evidence offered by the criminal defendant rather than by the government, the Confrontation Clause was not at issue. After substantial expansion of the hearsay exception in the 1980s, perhaps a perceived, although sometime unarticulated, need to satisfy the Confrontation Clause in criminal child abuse cases encouraged the prosecution and the courts to avoid testing the potential outer boundaries of the exception. 
questionable trustworthiness, my worst fears about how it might develop were not realized. The outer limits were tested and settled, and recently the exception has been applied somewhat more routinely.

Second, the exception has fractured, effectively becoming several distinct exceptions in different jurisdictions. Although settling on the number of significantly different versions is difficult, particularly if the judicial gloss given the exception is carefully examined, the jurisdictions can be grouped into two broad categories. One group attempts to ensure trustworthiness by requiring a connection between either the declarant's motivation or the circumstances of the examination and treatment, or otherwise requiring an examination of trustworthiness from the overall factual circumstances. ${ }^{6}$ For some jurisdictions in this group, statements made solely for diagnosis are inadmissible. For others, statements made solely for diagnosis are viewed with concern, and before they are admitted the context of the statements is scrutinized to determine if particular assurances of trustworthiness are present. ${ }^{8}$ Through differing mechanisms, these jurisdictions have eliminated the most problematic applications of the exception and have generally ensured a measure of trustworthiness across the range of its application.

A second group of jurisdictions, probably larger in total, admits statements under a reasonably straightforward interpretation of the rule that I believe fails in some situations to guarantee a minimal level of trustworthiness. In these jurisdictions, statements are admitted when made to medical doctors who are examining a child to determine if he or she has been sexually abused, without any necessary link to the child's appreciation of a treatment purpose. ${ }^{9}$ More significantly, those jurisdictions that follow a literal interpretation of the rule require neither a treatment atmosphere nor a treatment motivation of the declarant. Instead, all that is required is that the examination be conducted by a medical doctor, who offers the trial court an explanation why the statements elicited, including statements identifying the perpetrator of the abuse, might be useful to a diagnosis, given broad definition. ${ }^{10}$ Some of these jurisdictions exhibit more

6. Sometimes the required showing is stated as a list of factors. See, e.g., State v. Meeboer, 484 N.W.2d 621, 627 (Mich. 1991) (setting out a list of factors that would show trustworthiness). At other times, the requirement for admissibility is stated as the absence of features that suggest untrustworthiness. See, e.g., Kennedy v. State, 839 P.2d 667, 670 (Okla. Crim. App. 1992) (admitting a statement where there was no showing that the motivation "was anything other than for treatment"). The former is preferable to the latter, but even the latter is preferable to a wooden application of the rule across its broad scope that simply admits statements made for diagnosis separated entirely from a treatment motivation or environment.

7. See infra notes $172-74$ and accompanying text.

8. See infra notes $185-90$ and accompanying text

9. As discussed in Part V(B) of this article, I consider statements made shortly after an assault, where the atmosphere is clearly one that indicates that the purpose of the examination relates to treatment, to meet a reasonable level of trustworthiness, and I assume that is likely equivalent to the typical totality of the circumstances analysis references in the preceding paragraph. See discussion of the facts of White $v$. Illinois, infra notes 141-154 and accompanying text.

10. The discussion of the Tenth Circuit's approach and particularly its decision in United States $v$. Tome illustrates this approach. 61 F.3d 1446 (10th Cir. 1995). See infra notes 207-215 and accompanying text. 
concern about admitting statements made to social workers investigating abuse rather than to doctors, ${ }^{11}$ but often all that is required even as to social workers is that the interviews were conducted with an interest in determining where the child should be placed, ${ }^{12}$ or with an interest in offering psychological therapy at some time. ${ }^{13}$ In these jurisdictions, statements made in a highly adversarial setting are admissible.

The third observation reflected in the title is that the appropriate name for the exception as applied is the "medical examination exception."14 In a majority of jurisdictions, statements made for diagnosis purposes will be admitted when a child is sent to a pediatrician for a second opinion about whether abuse occurred. When a medical doctor is involved and the examination occurs shortly after discovering possible abuse, even more jurisdictions will admit statements without inquiring whether the child understood the treatment significance of the examination. Thus, the "medical examination exception" terminology captures the common denominator of the modern exception: When a medical examination is conducted, the child's statements are generally admissible.

Of these thr§ee conclusions, perhaps the most important is that the exception has disintegrated with respect to the core concepts of whether a treatment motivation of the "patient" must be shown directly or indirectly; whether trustworthiness must be otherwise demonstrated; or whether treatment motivation and an independent demonstration of trustworthiness are entirely unnecessary. In many jurisdictions and under a number of approaches, the Confrontation Clause $^{15}$ is satisfied by insistence on the traditionally required motivation for effective treatment, termed the "selfish treatment interest,"

11. See United States v. White, 11 F.3d 1446, 1449-50 (8th Cir. 1993) (excluding statement to social worker where there was no indication in record of social worker's role and relationship to diagnosis or treatment of child's injuries that might trigger child's motivation to provide truthful information). See generally infra notes 194-198 and accompanying text.

12. See, e.g., United States v. DeNoyer, 811 F.2d 436, 438 (8th Cir. 1987) (admitting testimony by social workers who interviewed a child in an attempt to ascertain whether the father was the source of the injury and to determine whether the child should be returned to father's care). But see, e.g., United States v. White, 11 F.3d at 1449-50 (excluding the statement to a social worker where there was no indication in the record of the social worker's role in diagnosing or treating the child's injuries that might trigger the child's motivation to provide truthful information).

13. See, e.g., United States v. Balfany, 965 F.2d 575, 579 (8th Cir. 1992) (admitting statements made by a child during individual sessions commenced before anticipated group therapy because of the social worker's belief that the child first needed individual attention).

14. In White v. Illinois, the Supreme Court referred to the exception in this shorthand fashion. 502 U.S. 346, 348, 351 (1992). The Court also referred to the exception as "statements made in the course of securing medical treatment," $i d$. at 350 , "receiving medical care," id. at 355, and "procuring medical services," id. at 356, and as the "'medical treatment" exception, Wright v. Idaho, 497 U.S. 805, 820 (1990), which suggests a narrower scope linked to treatment. The Court has also used the technically complete nomenclature, "statements made for the purposes of medical diagnosis or treatment." White, 502 U.S. at 356 n.8; Wright, 497 U.S. at 827.

15. The Sixth Amendment right to confront witnesses has a role in governing the admission of hearsay in criminal cases. As interpreted by the Supreme Court, the Confrontation Clause requires either the ability to confront and cross-examine those who made out-of-court statements, or some guarantee of the trustworthiness of the hearsay. See generally 2 MCCORMICK ON EVIDENCE $\S 252$ (5th ed. 1999).

16. See Mosteller, supra note 2, at 259. 
examination of trustworthiness. ${ }^{17}$ In other jurisdictions, trustworthiness is not guaranteed in either fashion. Indeed, in a majority of jurisdictions, accusatory hearsay may be admitted even though obtained in investigative settings of a decidedly adversarial character ${ }^{18}$ and lacking real guarantees of trustworthiness.

The disagreements between jurisdictions as to the factors that warrant admission remain numerous and substantial and have a potentially significant impact. I conclude that these disagreements are so significant that the exception admitting statements made to doctors and social workers identifying the abuser for the purposes of diagnosis alone is not "firmly rooted" under the Confrontation Clause. ${ }^{19}$

Part II reviews the major points of my earlier published analysis of this exception, emphasizing continuing areas of concern. Part III reviews both the direct impact of the reformulation of the traditional exception in Federal Rule of Evidence 803(4) ("Rule 803(4)") and its potential consequences. The drafters of the Rule were entirely oblivious to how their revisions might affect the admissibility of statements in child sexual abuse cases. Part IV turns to recent academic commentary, Supreme Court analysis, and rule variation and decisions in the lower courts. I examine what they reveal about the permissible bounds and the actual operation of this hearsay exception. As in later Parts, I find both maturation and disintegration of the exception.

Part V focuses on problems with the theory of the Rule in its present interpretation. The most problematic conceptual feature of the exception is its reliance upon the skill of the auditor (medical personnel broadly construed) to determine admissibility. I challenge both the adequacy of the theory that hearsay should be admissible on such a basis and the existence of adequate skill among

17. Among these are the states discussed infra in notes 173-175, 186-191, and accompanying text.

18. John E.B. Myers and Gail S. Goodman criticize those who stigmatize doctors who work in hospital-based child centers and in similar treatment/investigative units. See John E.B. Myers \& Gail S. Goodman, Hearsay Exceptions: Adjusting the Ratio of Intuition to Psychological Science, 65 LAW \& CONTEMP. PROBS. 3 (2002). I may be guilty of that fault here and in other parts of this article, but my point is more subtle and based on broad human experience. We are all affected by the expectations of our roles and by those with whom we associate and whom we aid. Doctors who act regularly as part of investigative teams are inevitably affected subconsciously by what they see and expect to see. This experience does not make them "witch hunters." It may, however, make them more prone to conclusions that favor the prosecution and cause them to ask questions and perceive responses as supporting those conclusions. When doctors perform the work of criminal investigators, they should be viewed at least partially as investigators and not wholly as neutral experts. As to some topics, such as the identity of the perpetrator, and to some circumstances, such as conversations not obviously connected with treatment, this investigative role should normally be seen as predominant, but even here, circumstances showing a genuine treatment motivation by the child can result in trustworthy statements that should be admissible.

19. The Supreme Court has decided that if a statement falls within a "firmly rooted" hearsay exception, the trustworthiness requirement of the Confrontation Clause is automatically satisfied for that statement. Ohio v. Roberts, 448 U.S. 56, 66 (1980). Notably, the interpretation of the evidence rule remains relevant even though the Confrontation Clause is generally not at issue if the child testifies. See United States v. Spotted War Bonnet, 933 F.2d 1471, 1473-74 (8th Cir. 1991) (ruling that the Confrontation Clause issue is generally eliminated by putting the declarant on the stand but recognizing that, as to extraordinarily mentally immature children, the constitutional issue may not be entirely eliminated). 
the auditors involved. ${ }^{20}$ Finally, Part VI discusses the impact of the Confrontation Clause and proposes an alternative solution that does not depend on reformulating the exception and that solves the most substantial of the problems catalogued in the analysis. I conclude that the current interpretation of the Rule that broadly admits statements identifying the abuser when the auditor's credentials are medically related both constitutes poor hearsay analysis and sometimes violates the Constitution. The exception should require some guarantee of trustworthiness outside the medical credentials of the auditor, even those of a pediatrician. I suggest a number of possible ways to satisfy those requirements, including returning to the common law formulation that turned on the declarant's selfish treatment interest.

\section{II}

\section{EARLIER EXAMINATION OF THE EXCEPTION}

In Child Sexual Abuse and Statements for the Purpose of Medical Diagnosis or Treatment ("my earlier article"), I analyzed how the exception and its theory were then being applied, stretched, and challenged by the peculiar problems presented when children are the source of evidence in prosecuting child sexual abuse. $^{21}$ I identified a number of areas of concern and suggested several approaches to eliminate or ameliorate problematic applications.

I noted a difference in application between statements made to medical experts, where statements are received for their truth, and those made to other experts, where they only support the expert's opinion. ${ }^{22}$ I set out possible justifications for that difference in treatment and examined how those justifications might suggest appropriate limitations on the categories of expertise covered by the exception. ${ }^{23}$

The prong of the exception allowing statements to be received when relied on only for the purpose of the expert rendering an opinion- "diagnosis" in the terminology of the rule-was generally problematic when applied in criminal cases and particularly troubling if extended broadly. I argued that experts should not be allowed to testify to statements made to them when they were not treating the patient and when the substantive law did not permit them to testify to an opinion. ${ }^{24}$ Also, because experts are uniformly not permitted to give an opinion on identity, statements identifying the perpetrator of abuse fall into this

20. Indeed, given the trends in modern evidence law that require greater evidentiary reliability for expert testimony and limit receipt of otherwise inadmissible evidence in support of expert opinions, it would be entirely appropriate to reform the medical examination exception to exclude statements whose admission rests on a diagnosis-only rationale that, in turn, rests upon the auditor's skill.

21. See generally Mosteller, supra note 2.

22. See id. at 261-62. There is a broad, although not unanimous, consensus among commentators and uniform acceptance by the courts that evidence received under Rule 703 to support an expert's opinion is not received for its truth and is therefore not a de facto hearsay exception. 2 MCCORMICK ON EVIDENCE, supra note 15, § 324.3, at 356 n.6.

23. Mosteller, supra note 2, at 267-69, 292 (suggesting that statements should be limited to those made to a highly skilled group of practitioners of medicine).

24. Id. at 267. 
inadmissible category. ${ }^{25}$ Extensions of the exception were most troubling when based solely on this diagnosis prong of the exception and applied to various psychological experts and esoteric conditions. ${ }^{26}$

Another set of concerns centered on use of this exception for statements relating to psychological maladies. One concern was whether the types of experts who treat such conditions have the requisite expertise to warrant different treatment for statements made to them as distinguished from all other experts. ${ }^{27}$ Another involved the almost limitless types of information that would be pertinent to treatment of such maladies. ${ }^{28}$ Perhaps the most significant concern was whether, as to psychological maladies, the selfish interest in treatment would be clear enough or substantial enough to provide an adequate guarantee of trustworthiness. $^{29}$

To address these issues, I made both broad and more specific suggestions. First, the Confrontation Clause should require different treatment for criminal cases, and if the statement was divorced from the selfish treatment interest, the exception should not be considered firmly rooted. ${ }^{30}$ Second, following the analysis described previously, under the diagnosis-only prong of the exception, experts should be permitted to testify to the statements only if they were permitted to render an opinion. ${ }^{31}$ Some limitation should be placed on the types of auditors allowed to offer statements for their truth, and specifically, statements to social workers outside a clear treatment environment might properly be excluded. ${ }^{32}$ Finally, when statements were made for the purpose of psychological well-being, courts should conduct a realistic, rather than a pro forma, analysis to determine whether the declarant was motivated by a selfish treatment interest. ${ }^{33}$

Although not stated explicitly, my underlying concern was that the exception might be used as a conduit for admitting accusatory statements, particularly

25. Id. at $280 \&$ n.97. An argument may be made that statements identifying the perpetrator as a family member can be helpful to a physician in deciding whether ambiguous physical injuries are the result of accidental contact or sexual abuse, because inter-family abuse is relatively common. See discussion of trial testimony in State v. Wright, infra note 127. Even if accepted as a justification for the expert utilizing the accusation, however, it should be excluded as excessively prejudicial under Rule 403 and particularly under the tougher admission requirements of the newly revised Rule 703, which mandates that otherwise inadmissible evidence may be received only if its probative value "in assisting the jury to evaluate the expert's opinion" "substantially outweighs" its prejudicial effect.

26. See Mosteller, supra note 2, at 292 (suggesting concern if the exception is extended to experts examining children to determine truth-telling ability). See also id. at 273 n.66.

27. Id. at $282-83$.

28. Id. at 283. See also 4 Christopher B. Mueller \& LAIRD C. KirkPATrick, Federal EVIDENCE $\S 442$, at 470 (1994) (noting that there is virtually "no limitation on what is relevant to psychological evaluation"). child).

29. Mosteller, supra note 2, at 281 (focusing especially on cases where the declarant is a very young

30. Id. at 285-90 (noting that the Confrontation Clause problem does not exist when the child testifies at trial and is subject to cross-examination regarding the statements).

31. Id. at 291-92.

32. Id. at $284,292$.

33. Id. at 291-93. 
regarding the identity of the perpetrator and the facts of a criminal offense..$^{34}$ The concern would be realized if statements were received under the diagnosisonly prong of the exception, applied in a formalistic fashion, and as a result, evidence that would not pass muster under a general catchall exception or an exception designed to cover children's statements in effect in many jurisdictions were admitted under this exception even though it lacked comparable indicia of trustworthiness.

This article attempts to take stock of how the exception has developed across the country since my earlier analysis. A number of developments are worthy of note. First, the Supreme Court has decided several relevant cases, including Idaho $v$. Wright ${ }^{35}$ and White v. Illinois, ${ }^{36}$ which directly involved hearsay and the Confrontation Clause in child abuse cases, and Williamson v. United States $^{37}$ and Lilly v. Virginia ${ }^{38}$ which analyzed hearsay and constitutional issues in other contexts. These cases provide some guidance about the minimal trustworthiness requirements of the Confrontation Clause and the role of the "firmly rooted" concept in regulating, or deregulating, admissibility. Second, in the field of evidence law generally, courts have more tightly restricted admission of questionable types and aspects of expert testimony under both Daubert v. Merrell Dow Pharmaceuticals ${ }^{39}$ and Kumho Tire Co. v. Carmichael. ${ }^{40}$ Additionally, a newly-revised Federal Rule of Evidence 703 ("Rule 703") more frequently will prevent the jury from hearing inadmissible evidence offered for the purpose of supporting an expert's opinion ${ }^{41}$ by creating a "presumption against disclosure to the jury of information used as the basis of an expert's opinion and not admissible for any substantive purpose." ${ }^{\prime 2}$ This presumption challenges the operating assumption of the Rules' drafters that expert opinion would be freely received and inadmissible evidence would be heard by the jury to support the opinion.

Third, new legal academic commentary has further examined the legal justification for the exception, and social scientists have begun to add useful empirical insights regarding the impact and dangers of hearsay evidence. Finally, and

34. Professors Christopher B. Mueller and Laird C. Kirkpatrick suggest that the exception can be misused by doctors and social workers who become "almost extensions of the offices of prosecutors and police, and in some urban hospitals special areas are set aside to collect statements by abuse victims in order to qualify them under the exception." MUELLER \& KIRKPATRICK, supra note $28, \S 442$, at 46465.

35. 497 U.S. 805 (1990).

36. 502 U.S. $346(1992)$.

37. 512 U.S. 594 (1994).

38. 527 U.S. $116(1999)$.

39. 509 U.S. 579 (1993) (requiring trial courts to exclude scientific evidence unless its evidentiary reliability is established by proving its scientific validity).

40. 526 U.S. 137 (1999) (ruling that Daubert's "gatekeeping" responsibility to ensure evidentiary reliability applies not only to scientific expertise but to all expert testimony).

41. Under the new rule, disclosure of otherwise inadmissible facts or data to the jury is forbidden "unless the court determines that their probative value in assisting the jury to evaluate the expert's opinion substantially outweighs their prejudicial effect.” FED. R. EVID. 703.

42. FED. R. EVID. 703 advisory committee's note (2000 amendment). 
most importantly, state and federal courts have decided scores of cases that provide a rich body of judicial experience with the exception, augmented by a few legislative and rule-making developments.

\section{III}

\section{THE IMPACT OF THE ENACTMENT OF THE FEDERAL RULES}

\section{A. Specific Changes and Conceptual Shifts Made by Rule 803(4)}

As the cases cited in this article and my earlier examination of this exception demonstrate, a large number of child sexual abuse cases have been decided under Federal Rule 803(4) and its counterparts in the states. ${ }^{43}$ Indeed, although such prosecutions comprise a small percentage of criminal cases, they comprise the bulk of reported cases dealing with the medical examination exception. There is, however, absolutely no indication that the drafters of the Federal Rules of Evidence anticipated such a role for the exception in child sexual abuse prosecutions. If, in the early 1970s, the drafters foresaw the issues that would dominate the legal discussion of the exception in the ensuing decades, they certainly gave no hint. Rather, it appears they were oblivious to what would be substantial unintended consequences.

The drafters certainly did intend to change the exception from its orthodox common law formulation, making three major changes. First, the exception includes patients' statements of their medical histories, along with statements relating to then-existing conditions. Second, it covers statements going to the general cause of the injury or condition when pertinent to diagnosis or treatment, while continuing to exclude statements of fault. ${ }^{44}$ The first of these changes flowed from the long-standing rationale that a patient can be expected to speak accurately and truthfully to those determining appropriate medical care, whether for present or past symptoms. Similarly, statements regarding cause when linked, as by the Advisory Committee's note, to medical pertinency and limited to exclude statements of fault fall within the trustworthiness rationale. ${ }^{45}$ Although these changes were important, they constituted clarifications of the implications of the exception's rationale to frequently encountered situations and a consolidation of the progressive legal trends, rather than major theoretical departures.

The third change in the exception was much more conceptually adventuresome, and its consequences have proved significant and controversial. In this modification, the exception moved beyond statements for the purpose of treating the patient's condition to include those made to "a physician consulted only for the purpose of enabling him to testify." ${ }^{46}$ This change was accomplished by

43. Indeed, civil cases unrelated to child abuse involving the exception, such as Cook v. Hoppin, 783 F.2d 684 (7th Cir. 1986), and Gong v. Hirsch, 913 F.2d 1269 (7th Cir. 1990), are a relative rarity.

44. FED. R. EVID. 803(4) advisory committee's note.

45. $I d$.

46. $I d$. 
joining the terminology "for the purposes of medical diagnosis" in the exception disjunctively with statements made for the purposes of "treatment."

As to the third change, the significant conceptual innovation was admitting hearsay statements because those who heard the statements relied upon them. The Advisory Committee allowed such statements to be received for their truth under the rationale that the jury was unlikely to appreciate the distinction between statements received to support an opinion, traditionally heard by the jury if "of a kind ordinarily relied upon by experts in the field," into evidence for their substance. ${ }^{48}$ The decision to recognize the likely misuse of evidence by jurors who would ignore limiting instructions seemed sensible, although hardly adequate to justify a major alteration in the theoretical basis of the admission of hearsay.

Thus, under the revision, the exception has two distinct and independent theoretical bases for admitting hearsay. The first is the traditional justification-the patient's selfish treatment interest. Under it, patients are assumed to be motivated to give truthful statements to those seeking information for the purpose of treating the patient's condition. Unless the patient provides such information, he or she should expect treatment to be inadequate and misguided, and his or her health to suffer as a result. This type of theoretical justification concerning the motivation of the declarant is a sufficient guarantee of the trustworthiness under traditional hearsay analysis. ${ }^{49}$ The second justification rests on the expert's reliance. In the terminology of Jack B. Weinstein and Margaret A. Berger, "[a] fact reliable enough to serve as the basis in the statement to form a diagnosis is also reliable enough to escape the hearsay proscription. ${ }^{50}$

Two questions have troubled courts and commentators since the enactment of the Rule. First, why are statements made to medical experts, which are received for their truth, treated differently from statements to other experts? The Advisory Committee gave no direct explanation. My earlier article surveys and analyzes possible reasons to give medical professionals special status:

First, procedural rules governing the discovery of opinions by [medical] experts give a special guarantee of their reliability since such statements will be more thoroughly tested by the adversary process than others. Second, medical experts compose a group of highly skilled and carefully trained professionals. Third, because of the size and the maturity of the medical profession, an established group of experts will be available to both sides in the litigation to test thoroughly any opinion and the reliability of the statements forming its foundation. Finally, arguably, medical experts are part of a "harder" and more precise science than many of the fields in which individuals can

47. $I d$.

48. $I d$.

49. The Court in Idaho v. Wright, 447 U.S. 805 (1990), cited Wigmore's analysis of the theory of hearsay trustworthiness. See generally 5 JOHN HENRY WigMORE, EVIDENCE $§ 1420$, at 251 (James H. Chadbourn rev. 1974). The Wright Court adopted this analysis as a theory of why cross-examination was not needed to test reliability under the Confrontation Clause. Wright, 497 U.S. at 819-20 (1990). See also infra note 221.

50. 5 JACK B. WEINSTEIN \& MARgARET A. BERGER, WEINSTEIN'S FEDERAL EVIDENCE $\S 803.09[4]$, at 803-44 (Joseph M. McLaughlin ed., 2d ed. 2000). 
presently be certified to give expert testimony under the liberal standards of the Federal Rules.

During the succeeding decade, no one has unearthed documentation of the drafters' thoughts or suggested better or different justifications for special treatment of statements to medical professionals. ${ }^{52}$

Second, was there an intention to include in the exception statements made to those treating psychological as opposed to somatic problems? My earlier article suggests that, while the words of the exception do not contain an intent to so limit it, certainly the problems are more complex if psychological experts are included. ${ }^{53}$ As a consequence, perhaps the exception should be limited to medical professionals who treat somatic maladies as opposed to those who treat psychological conditions. ${ }^{54}$

Perhaps more puzzling than either of these questions is why the drafters picked out any particular set of experts whose reliance would render statements admissible for their truth. The Advisory Committee's assertion that their actions were "consistent with the provision of Rule 703" is clearly inadequate because statements received as to other experts are not substantively admissible. ${ }^{55}$ The drafters gave every impression that they believed they were doing nothing of great significance but were instead merely "tidying up" to eliminate a minor technical problem. Professor Ed Cleary, reporter for the Advisory Committee, made the clearest statement of this perspective to the House Judiciary Committee:

Admissible statements to physicians are not required to have been made for diagnosis and treatment but are allowable if for either. Thus the practice of allowing in the pa-

51. Mosteller, supra note 2, at 263. The procedural rules include discovery rules that entitle a party to obtain copies of the adversary's medical reports prior to trial, and, in civil cases, permit the court to order a physical or mental examination. $I d$.

52. John J. Capowski, An Interdisciplinary Analysis of Statements to Mental Health Professionals under the Diagnosis or Treatment Hearsay Exception, 33 GA. L. REV. 353, 362-63 (1999) (focusing on the argument of trustworthiness based on an expert's reasonable reliance). For a general discussion of the recent academic commentary, see notes 82-109 and accompanying text. Moreover, I can find no reference to these issues even being discussed in any of the published legislative materials. See JAMES F. Bailey \& Oscar M. Trelles, The Federal Rules of EVIDEnce: Legislative Histories AND RELATED DOCUMENTS (1980) (a four-volume compilation of legislative history).

53. Several factors coalesce when psychological experts are involved. The degree of selfish treatment interest may be diminished, the range of pertinent information is expanded, and the wide variety of experts who provide psychological treatment mean that basing trustworthiness on the special skill and training of these experts is particularly problematic. See Mosteller, supra note 2, at 281-84. But see Capowski, supra note 52, at 389-90 (arguing that psychological experts are trained to discern deception).

54. A few jurisdictions treat statements related to psychological maladies differently than those related to somatic conditions. See infra notes 184-188 and accompanying text.

55. FED. R. EVID. 803(4) advisory committee's note. The claim of consistency may also be somewhat inaccurate. Although it describes the general situation when an expert could have used inadmissible evidence to support an opinion under the original formulation of Rule 703 and when hearsay in support of medical diagnosis would be received under Rule 803(4), its terminology— "ordinarily relied upon"-is both technically and substantively different than the "reasonably relied upon" language of Rule 703. L. Timothy Perrin, Expert Witnesses under Rules 703 and 803(4) of the Federal Rules of Evidence: Separating the Wheat from the Chaff, 72 IND. L.J. 939, 945-46 (1997) (noting that the terminology is different and arguing that its use would produce an improper application of Rule 703). 
tient's statements to a physician examining in order to testify, but only as a basis for the expert opinion, found in some jurisdictions, is squared with reality.

Major theoretical and substantive reform was not contemplated. The drafters appeared to seek only to mesh law with reality.

The drafters' model for the new rule was the garden-variety civil case in which a litigant visited a doctor seeking an examination for use at trial. ${ }^{57}$ In those cases, the doctor would be required to testify at trial if his proposed evidence included an opinion favorable to the party that secured the diagnosis. ${ }^{58}$ The party/"patient" would be subject to discovery regarding the facts of his or her condition and treatment and required to submit to another examination by

56. Reform of Fed. Criminal Laws: Hearings Before the Special Subcomm. of the House Comm. on the Judiciary, 93d Cong. 91 (1973) (statement of Ed Cleary, Reporter, Advisory Committee), reprinted in 3 BAILEY \& TRELLES, supra note 52, at 91 (1980). Cleary's interpretation of the Rules should carry great weight. As the Court stated in Tome v. United States, Cleary was the Reporter of the Advisory Committee that drafted the Federal Rules, and the Court had "relied upon his writings as persuasive authority on the meaning of the Rules." 513 U.S. 150, 162 (1995) (citing Daubert v. Merrell Dow Pharms., Inc., 509 U.S. 579 (1993), and United States v. Abel, 469 U.S. 49, $51-52$ (1984)).

57. The few references in the legislative history to Rule 803(4) support this position. The Judiciary Committees of the House and Senate responded to concerns that the rule not be considered to affect privilege rules when a physical examination was given solely to enable a physician to testify. See STAFF OF House COMM. ON THE Judiciary, 93D CONG., RepORT ON FEDERAl Rules OF EVIDENCE 14, reprinted in 4 BAILEY \& TRELLES, supra note 52; STAFF OF SENATE COMM. ON THE JUDICARY, 93D CONG., REPORT ON FEDERAL RULES OF EVIDENCE 26, reprinted in 4 BAILEY \& TRELlES, supra note 52. The Senate noted with regard to this concern that Rule 35 of the Federal Rules of Civil Procedure requires the party to submit to a physical examination by the adverse party, which would normally be admitted under this exception when the physical or mental condition of the party is at issue. Id. The concerns discussed clearly pertain to applying the exception within the context of ordinary civil litigation.

A few others raised issues about the appropriateness of the rule's expansion, but only concerning its use by parties to advance their cause in apparently garden-variety civil litigation. Professor Francis Paschal argued that state law should be applicable when statements were made for the purpose of medical diagnosis, since many states' rules would deny admissibility, which reflected the states' judgment of how easy it ought to be for the plaintiff "to get to the jury on questions of casuality [sic] and physical condition." Testimony of Prof. J. Francis Paschal, Duke University School of Law, Durham, N.C. at 88,91 , reprinted in 4 BAILEY \& TRELlES, supra note 52 . The recommendations of the Study Committee on the Federal Rules of Evidence of the District of Columbia Bar argued that the exception was too broad in admitting a statement made to a physician consulted solely or primarily for the purpose of using the doctor as an expert at trial, since the patient's motivation might not be toward candor but rather toward supporting falsification, omission, and exaggeration. To illustrate the issue, it cited Nutt v. Black Hills Stage Line, Inc., a garden-variety civil accident case. 552 F.2d 480, 483-84 (8th Cir. 1971). See Reform of Fed. Criminal Laws: Hearings Before the Special Subcomm. of the House Comm. on the Judiciary, 93rd Cong. 278 (1973), reprinted in 3 BAILEY \& TRELlES, supra note 52, at 288. Similarly, the Report of the Subcommittee on Proposed Rules of Evidence, Federal Bench-Bar Committee, Connecticut Bar Association, criticized this proposed expansion because, when moving beyond statements for medical treatment, "[t]oo much room would be permitted for abuse if a physician could come in an[d] testify as to self-serving statements made by a patient." Id. at 278.

Nowhere in the legislative history materials assembled by James F. Bailey and Oscar M. Trelles does anyone note the possibility of using the exception's expansion in criminal prosecutions. See generally BAILEY \& TRELLES, supra note 52. There is no indication that anyone foresaw the possibility of the exception playing the role it currently does in child sexual abuse prosecutions.

58. Under well-established common law authority, reports prepared by doctors in preparation for litigation could not be received under the business records exception when the reports supported the position of the party securing the report. See, e.g., Yates v. Bair Transport, Inc., 249 F. Supp. 681, 68891 (S.D.N.Y. 1965). If, therefore, evidence from a physician examining a party for the purpose of testimony was to be received, the doctor would be required to testify and submit to cross-examination. 
the adversary's expert. ${ }^{59}$ The party/"patient" would testify or be called as an adverse witness, and, in either situation, could be subjected to crossexamination. Under these circumstances, excluding the declarant's statements or limiting their admissibility to supporting the doctor's opinion presented more opportunities for meaningless quibbles, costly appeals, and needless reversals than for substantive harm resulting from admitting the statements for their truth. Perhaps the drafters envisioned an experiment with a new rationale for receiving hearsay that might be applied more generally, but, if so, they gave no hint. Rather than trail-blazing, they thought they were eliminating an insignificant nuisance and squaring practice with reality.

As is often the case, unforeseen social developments produced a new context for application of the exception, which led to unanticipated legal developments. The country began to acknowledge that children were physically and sexually abused in shocking numbers. ${ }^{60}$ As these cases moved into the court system, the new elements of the exception provided new theoretical pathways for admission of hearsay.

The long-standing exception permitted the receipt of a statement by a child, or an adult, regarding the nature of a condition. Including medical history extended the exception to statements typically made in child sexual abuse cases where the event is not discovered for some period of time. Admitting statements regarding the general cause of the injury admitted evidence of the injury's general nature and allowed, for example, a description of a sexual assault to be received. These changes helped provide a stage for an arguably much more important extension.

B. Changes Interpreted to Allow the Perpetrator to be Identified

The most significant new evidence admitted under the new provisions of the exception, almost certainly unanticipated by the drafters, is statements identifying the perpetrator. The Advisory Committee's note drew a distinction between cause and fault, illustrating the difference with an automobile injury case. ${ }^{61}$ The patient's statement that he was struck by a car relates to cause, and his statement that the car that struck him ran a red light relates to fault. While statements of causation reasonably pertinent to diagnosis or treatment are admissible under the Rule, statements of fault remain inadmissible, because they are not ordinarily medically pertinent. ${ }^{62}$ Under this dichotomy, statements iden-

59. FED. R. CIV. P. 35.

60. See Lucy S. MCGough, Child Witnesses: Fragile Voices in the American Legal SYSTEM 10 (1994) (noting that reform in evidence law regarding children was spurred on by several notorious "day care" cases and by gathering national statistics that showed an enormous increase in reported cases from the mid-1970s to the mid-1980s).

61. FED. R. EvID. 803(4) advisory committee's note.

62. Id. 
tifying the perpetrator appear to be excluded because the identity of the perpetrator more closely resembles fault than cause. ${ }^{63}$

In child sexual abuse cases, such identifying statements are often significant. Unlike a statement to a doctor consulted to prepare trial testimony in the typical civil case, statements identifying the perpetrator are not so easily replicated through the declarant's trial testimony. The child may be unwilling or unable to testify at trial. If the child does testify, the testimony may be halting and incomplete, and as a result, potentially lacking in credibility. A statement made to an adult relatively soon after the event is sometimes the only statement identifying the defendant in the case, and a statement to an adult with impressive, neutral credentials, such as a medical professional, may be particularly persuasive..$^{4}$

Thus, admitting identifying statements of great consequence cannot be justified on the basis that jurors are unlikely to pay much attention to a limiting instruction. If the statement constitutes the only direct evidence that the defendant is the perpetrator, admitting the evidence for its truth may turn a directed verdict for the defendant at the end of the prosecution's case into a conviction. When the hearsay statement is far more detailed and powerful than the child's testimony ${ }^{65}$ or when the statement acts as critical corroboration for the jury of the child's in-court assertions, it may mean the difference between an acquittal and a guilty verdict. ${ }^{66}$

63. See United States v. Iron Shell, 633 F.2d 77, 84 n.10 (8th Cir. 1980) (rejecting the identification of the perpetrator under the exception and drawing the connection between that rejection and the cause-fault distinction in the Advisory Committee note).

64. David F. Ross et al., The Impact of Hearsay Testimony on Conviction Rates in Trials of Child Sexual Abuse: Toward Balancing the Rights of Defendants and Child Witnesses, 5 PsYCHOL. PUB. POL'Y \& L. 439, 451-53 (1999) (finding that, in a simulated trial setting, hearsay offered by apparently neutral witnesses with professional status regarding child abuse allegations is particularly persuasive).

65. Cf. Tome v. United States, 513 U.S. 150, 153, 165 (1995) (reversing a conviction based on the government's presentation as prior consistent statements of "a parade of sympathetic and credible witnesses" who recounted the child's detailed out-of-court statements to them, which contrasted with the child's direct testimony, which had consisted of one- and two-word answers to a series of leading questions, and cross-examination when the child had often been reluctant to answer questions about abuse).

66. Cf. John E.B. Myers et al., Jurors' Perceptions of Hearsay in Child Sexual Abuse Cases, 5 PSYCHOL. PUB. POL'Y \& L. 388, 397, 412, 414 (1999) (finding that, in an empirical study of jurors from forty-two sexual abuse cases in which one or more adult witnesses testified in each case to hearsay from one or more children, the child's pre-trial statements were more believable than statements made in court, and jurors' perception of the hearsay witnesses' credibility was significantly related to guilty verdicts).

While consistent with an important role for adult hearsay witnesses in support of the children's testimony, Professor Myers's study reflects a picture somewhat inconsistent with that portrayed above. In his database, which came from one city in Arizona and one in California, the child testified in each of the cases. Id. at 397, 411. Furthermore, while the hearsay statements played an important role in jurors' decisionmaking, id. at 417 , the most important factors were the children's testimony and the defendants' statements, $i d$. at 408 . The children's in-court testimony was more important to guilt decisions than pretrial statements. Id. at 412. Some of Professor Myers's descriptive information, however, fits perfectly with the image described above. The child was reluctant and incomplete in her in-court testimony, but the testimony was supported by more detailed descriptions of the event before trial. Id. at 413. While hard to unpack, the interplay between the hearsay and the in-court evidence appeared important in supporting and supplementing what the children offered in their testimony. 
Moreover, the Advisory Committee's justification for receiving an identifying statement is not readily apparent in this situation. The expert would typically be prohibited from opining as to the identity of the perpetrator. ${ }^{67}$ As a result, the statement of the child could not be received in the absence of the hearsay rule to support what would be an inadmissible opinion.

Then why have courts generally found identifying statements admissible? In answering this question, the different rationales for admission take on special importance. The typical reasonable person/declarant would not likely consider a statement to a doctor identifying the perpetrator of a sexual assault to be critical to proper medical treatment. Perception could well change if the doctor explained the significance of the identifying evidence to appropriate treatment and thereby convinced the declarant of its importance to a selfish treatment interest. From the declarant's perspective, it is not clear why a statement identifying the perpetrator would have medical significance different from or more powerful than a statement to representatives of law enforcement. These statements are often highly accusatory and more relevant to prosecution than treatment. Thus, absent a persuasive explanation of pertinence from the medical professional, if admissibility turns on the speaker's motivation, the auditor's status as a medical professional hardly provides an impressive basis for admissibility.

Rather than the declarant's perception, the most direct path to admissibility is the expert's reliance upon the information, not as the basis for an admissible opinion, but as pertinent to the auditor's judgment about potential treatment. The new element of the Rule that allowed admission of evidence when relied upon by the expert likely proved central to the courts' general acceptance of such statements. ${ }^{68}$ In those jurisdictions where identifying statements were first admitted, the justification turned on the pertinence ascribed to the statement by the medical professional. The critical perspective was the doctor's view of pertinence, not the patient's. ${ }^{69}$

67. See, e.g., State v. Lucero, 863 P.2d 1071, 1075 (N.M. 1993) (ruling that testimony by a psychologist repeating the name of the perpetrator is inadmissible because the profession has no "truth-telling machine'"); State v. Alberico, 861 P.2d 192, 211-12 (N.M. 1993) (establishing limits on testimony by a psychologist regarding rape-trauma syndrome that excludes diagnosis of a crime or identification of the perpetrator). See generally Robert P. Mosteller, Syndromes and Politics in Criminal Trials and Evidence Law, 46 DUKE L.J. 461, 469-72, 483-84 (1996) (noting that, based on psychological features, determining the cause of a condition is generally not scientifically possible or legally permissible).

68. Goldade v. State is one of the oldest and most influential cases regarding the acceptance of these statements. 674 P.2d 721 (Wyo. 1983). There the court stated:

In reaching a conclusion as to pertinency ... the courts must rely upon the view of the treating physician or the views of other medical service personnel with respect to what facts are pertinent to diagnosis and treatment.... They ... must decide whether the child may be in imminent danger, which determination is necessary in determining the propriety of temporary protective custody. In the absence of information as to the identity of any assailant of the child this latter decision cannot be made in a rational way. Id. at 726 .

69. Nothing in the rule's legislative history suggests that this analytical twist was anticipated by the drafters of the rule. See FED. R. EVID. 803(4) advisory committee's note; BAILEY \& TRELLES, supra note 52 . 
Several justifications for why the identification of the perpetrator is pertinent to medical concerns have been offered. The one most resembling ordinary analysis under this exception is that the identity of the perpetrator is relevant as the possible source of sexually transmitted diseases. ${ }^{70}$ Another argument is that the doctor may have a legal duty or care-related interest in eliminating contact with the perpetrator when that person is a member of the child's household or would have ready access. ${ }^{71}$ Finally, the medical expert, if interested in psychological well-being, may consider the perpetrator's identity important under the theory that abuse by intimates creates different psychological harm than abuse by strangers. ${ }^{72}$ While these justifications bear on treatment broadly construed, they relate to the professional's perspective, not to the "patient"/declarant's.

\section{The Impact of Rule Changes on Other Issues}

Two relatively distinct types of issues add complexity to the reformulated exception. First, must the patient perceive the information as pertinent to treatment, whether determined independently or after the treating individual has explained the importance of the information to proper treatment, or may the expert alone view the information as pertinent? Second, are placement of the child and the other issues described in the preceding section medically pertinent under the exception?

When these basic concerns are applied to the modern circumstances encountered in child sexual abuse prosecutions, a complex set of issues is generated, including concerns regarding: (1) treatment versus diagnosis; (2) the patient's view of the pertinence of the information versus the expert's view; (3) medical versus psychological treatment; (4) cause versus fault; (5) physician versus psychologist or psychiatrist versus social worker; (6) contemporaneous statements versus delayed conversation; (7) spontaneous reports versus long-

70. United States v. George, 960 F.2d 97, 99 (9th Cir. 1992). An analogy can be seen in admitting statements regarding the location of an injury as possibly relevant to the doctor's determination of whether to be particularly concerned about infection. See 4 MUELLER \& KIRKPATRICK, supra note 28, $\S 442$, at 458-59 (arguing for a broad construction of pertinency standards outside the context of child abuse prosecutions regarding issues such as danger of infection and to broadly determine the physical facts of the injury).

71. See United States v. Renville, 779 F.2d 430, 438 (8th Cir. 1985) (noting that physicians have an obligation imposed by state law to prevent abused children from being returned to a place where they cannot be protected, which is most immediate where the abuser is a member of the victim's household).

Professors Mueller and Kirkpatrick argue that this type of information is not part of any special medical expertise and therefore does not satisfy the pertinency requirement intended by the rule. Rather, they contend, it involves "providing social remedies aimed at determining abuse, identifying and punishing abusers, and preventing further mistreatment, which involves skills and social intervention lying beyond the expertise of doctors." Id. $\S 442$ at 464 . Their argument has generally not been accepted by the courts. But see Cassidy v. State, 536 A.2d 666, 682-83 (Md. Ct. Spec. App. 1988) (excluding statement that went to social disposition, which the court considered distinct from medical treatment upon which the exception is based and stating that, "in the context of child abuse, the physician wears two hats [but] [o]nly one of those hats ... relates to this particular hearsay exception").

72. See State v. Robinson, 735 P.2d 801, 810 (Ariz. 1987) ("The psychological sequelae [sic] of sexual molestation by a father, other relative, or family friend may be different and require different treatment than those relating to abuse by a stranger."). 
running interviews; and (8) independent and neutral physician versus member of investigative team.

In addressing this range of issues, substantial differences in analysis often turn upon the theory of admissibility used. For example, if the statement is admitted because of the patient's selfish treatment interest, the child must have the mental capacity to perceive and understand the significance of the statements for her health, and she must recognize the connection between the statements and health in general. Statements by individuals other than the child/victim may be received under this theory, but an affinity must exist between the speaker and the child/victim, as well as a perceived connection to the latter's well-being. On the other hand, if the statement is received to support an expert's opinion, the child's age and ability to understand the importance of the statement to well-being largely drops out of the analysis. With a diagnosis-only focus, social concerns that relate to placing the child and detecting crime can be more easily incorporated into "medical" pertinence. ${ }^{73}$ Statements of third parties without emotional connection to the patient are also potentially admissible if helpful to the medical expert.

The alternative theory of admissibility depends on the expert's reliance upon the hearsay. Ultimately, admissibility under this theory is justified on the basis that the auditor's special status and abilities provide an adequate guarantee of trustworthiness. This justification, however, proves inadequate, particularly in situations where statements identifying the perpetrator are made to doctors or social workers who are part of a prosecution team. Such statements are pertinent to social placement, which is not an area in which medical professionals have special expertise. The Supreme Court's decisions in Daubert and Kumho Tire make it clear that juries should not hear unreliable expert testimony, and, under those holdings, medical professionals are prevented from directly testifying to a diagnosis naming the perpetrator. ${ }^{74}$ Without the ability to diagnose identity, experts have little basis to correct or comment on statements made to them regarding identity. Moreover, since they are not allowed to testify to an opinion on the issue, statements made to them regarding identity would not be presented to the jury to support the opinion.

\section{The Principal Problematic Result and Some Possible Solutions}

The medical examination exception should not constitute a conduit for unreliable, particularly accusatory, hearsay under either the soundly applied hearsay rule or under the Confrontation Clause. An exception that admits statements simply because they fit the technical requirements of the basis of the expert's opinion threatens both accuracy and justice.

73. See Cassidy, 536 A.2d at 686-87 (describing how, in United States v. Renville, 779 F.2d 430 (8th Cir. 1985), the Eighth Circuit brought social disposition within the exception by focusing exclusively on pertinence from the physician's perspective).

74. See generally Kumho Tire Co. v. Carmichael, 526 U.S. 137 (1999); Daubert v. Merrell Dow Pharms., Inc., 509 U.S. 579 (1993). 
Two alternatives are available. The first is to redefine the exception to cover only statements made for the purpose of treatment, eliminating the illadvised extension of the exception to cover statements made for diagnosis alone, ${ }^{75}$ and also realistically determining whether a statement is made with a selfish treatment interest. ${ }^{76}$ The second acknowledges the complexity of approaches across the jurisdictions and requires some method of ensuring trustworthiness where selfish treatment interest is not directly required. If accompanied by an examination of contextual factors to assure trustworthiness, ${ }^{77}$ the second alternative, although lacking elegance and simplicity, ${ }^{78}$ allows the exception both to be helpful to the prosecution of these difficult cases and to meet acceptable levels of trustworthiness.

I will concentrate principally on the second of these approaches largely for practical reasons. The most likely route to reform is to impose modest limitations on the experience and developments of the last twenty years, rather than through widespread reversion of the exception to its pre-Federal Rules formu-

75. I want to thank John Myers for reminding me that revision of the rule is the purest way to eliminate the major problems encountered in its application to child abuse cases. See Myers \& Goodman, supra note 18, at 8 . While he and I would differ on the appropriate limitations on that redefined exception, his proposal is conceptually quite sound. This article, however, moves in two different directions. While it encourages adoption of a selfish treatment interest definition, it assumes that no widespread redefinition of the exception will occur, although clearly an appropriately narrow definition of the exception has been adopted in five states by statute and one by recent court ruling. See infra notes 173-174 and accompanying text. While recognizing the complexity of approaches to this exception throughout the jurisdictions, this article seeks to suggest ways to channel the application of the law to eliminate the worst abuses and the applications most likely to lead to erroneous outcomes.

76. As noted in the final recommendation, if the exception is to maintain theoretical integrity, statements must not be considered to have been made with selfish treatment interest simply because a medical professional informed the child that the information was important for treatment. Such a statement should, of course, be considered for its impact on the child, but the circumstances of the statement that support or undercut the connection of the information to treatment and the comprehension of the child must be considered as well. The motivation of the child is the key, and courts should not presume it to be automatically altered by a verbal ritual. See infra text accompanying note 252 .

77. Adding this contextual-factors requirement should be substantively acceptable because both the catchall exception and the special state exception for statements of children are available as alternative routes for admission; both utilize contextual factors to establish trustworthiness. A statement admissible under the catchall does not additionally damage substantive concerns about accuracy when admitted under Rule 803(4). Thus, modifications of the medical examination exception have no great substantive impact if such contextual factors supporting trustworthiness are required to the same degree under this exception as under the catchall. A similar contextual analysis, excluding any reliance on external evidence corroborating the truth of the statements, should also satisfy the Confrontation Clause.

78. My earlier article argued that a sound and perhaps elegant solution was needed to avoid distortion of the medical examination exception to avoid misapplication in other areas. See Mosteller, supra note 2, at 293-94; see also Robert R. Rugani, Jr., Comment, The Gradual Decline of a Hearsay Exception: The Misapplication of Federal Rule of Evidence 803(4), The Medical Diagnosis Hearsay Exception, 39 SANTA CLARA L. REV. 867, 903 (1999) (arguing for the use of a child-specific exception to allow a more consistent and predictable application of this specific exception). It now appears that this specific exception has only one major application and problem area: its application in child abuse cases. Fixing the immediate problem of how the exception is applied in this area should be the chief concern; articulating the potential for possible distortions in other areas can easily wait until another day. 
lation. $^{79}$ My analysis, however, supports the simpler but more fundamental solution of redefining the rule to admit only statements supported by a selfish treatment interest. ${ }^{80}$ That change provides the most direct remedy to the problems identified. Regardless of which route to reform is taken, one major theoretical issue should be settled. The identity of the auditor as an expert, whether a doctor or another type of expert, should not be grounds for admission of hearsay in an accusatory context. ${ }^{81}$

\section{IV}

\section{ANALYSIS AND DEVELOPMENTS RELEVANT TO SHAPING THE EXCEPTION}

\section{A. Academic Commentary}

Over the last few years, a limited but helpful legal academic commentary has developed regarding the exception. Social scientists are also beginning to develop a body of theoretical and empirical research focused on the impact and the dangers of hearsay evidence. This section will first discuss the legal commentary and then the social science research.

The most notable of the legal academic articles on the exception is by Professor John Capowski, who makes two principal arguments. ${ }^{82}$ First, statements for the purpose of diagnosis without a view for treatment should not be admitted under the exception. ${ }^{83}$ Second, statements made to mental health professionals in an ongoing treatment relationship should be received, and are sufficiently trustworthy, under a selfish-treatment-interest rationale. ${ }^{84}$

Professor Capowski argues that statements solely for diagnosis should be excluded from the exception because the major justification for their admission-that "a fact reliable enough to serve as the basis for a diagnosis is also reliable enough to escape the hearsay proscription" ${ }^{\circ 5}$-is insufficient. This justifi-

79. The decision of the North Carolina Supreme Court in State v. Hinnant, which returned the exception to a pre-Federal Rules definition, demonstrates, however, that a conceptually clean break is feasible. 523 S.E.2d 663 (N.C. 2000).

80. Specific examples of this analysis include discussions of academic commentary criticizing a hearsay exception based on the skill of the auditor, as well as the developing trends in evidence law that restrict admission of expert testimony and impose higher barriers on presenting to the jury otherwise inadmissible evidence supporting an expert's opinion. See discussion infra Parts IV.A., V.A.

81. Experts may rely on hearsay in forming opinions admissible under Rules 803(6) and Rule 803(8)(C). Hearsay created in an adversarial setting in preparation for trials is, however, categorically excluded under Rule 803(8)(B) and (C) in criminal litigation. In both rules, the fact that the opinion was generated for litigation is a factor to be counted against admissibility as one of the "circumstances of preparation [that may] indicate lack of trustworthiness." FED. R. EVID. 803(6) \& 803(8) advisory committee's note (discussing Palmer v. Hoffman, 318 U.S. 109 (1943)).

82. See Capowski, supra note 52 .

83. Id. at 399-404.

84. Professor Capowski finds trustworthiness equivalent "if [the patients] perceive honesty as appropriate. Psychological counseling is likely to be just such a setting, especially if it is ongoing." Id. at 387.

85. WEINSTEIN \& BERGER, supra note 50, at 803-57 (quoting United States v. Iron Shell, 633 F.2d 77, 87 (8th Cir. 1980)). 
cation overlooks the facts that expert skill and integrity can be counteracted by attorney manipulation, ${ }^{86}$ and that even experts operating with integrity have limited ability to discern falsehood, ${ }^{87}$ a capability upon which some commentators argue this exception relies. ${ }^{88}$ Professor Capowski notes that this exception stands alone in basing reliability on the ability of the auditor and asserts that this ability is clearly an inadequate basis for admissibility. ${ }^{89}$

Professor Timothy Perrin analyzes the provisions of Rule 803(4) regarding statements to medical experts, which are admitted for their truth, in conjunction with the provisions of Rules 703 to 705 governing reliance and admission of statements to experts which are admitted only to support the experts' opinions. ${ }^{90}$ Relying on several factors, including the partisanship of experts selected to testify, ${ }^{91}$ he argues that diagnosis should be eliminated as a separate basis of admission of hearsay statements under Rule 803(4). ${ }^{22}$ He believes experts who participate in an event are typically more reliable than those who are chosen to conduct examinations for trial. Although motivation and potential for manipulation do not always vary between the two situations, those factors generally disfavor receiving hearsay statements from experts chosen to prepare trial testimony, or in the terminology of Rule 803(4), statements for diagnosis. ${ }^{93}$ Like Professor Capowski, Professor Perrin notes the uniqueness of this exception in admitting hearsay based on validation by the auditor and finds no justification for relying on that type of validation when the expert is selected to provide testimony, a circumstance that is commonly recognized to create suspect motivation. $^{94}$

Lynne DeSarbo's comment makes several arguments, one directly opposing a point made by Professor Capowski and another in agreement. ${ }^{95}$ DeSarbo contends that the therapeutic relationship in mental health treatment is inconsistent with patient motivation to be truthful, because the role of the treating indi-

86. See Capowski, supra note 52 , at $400-01$.

87. Id. at 402 .

88. Professor Capowski notes that both the Colorado Supreme Court and Weinstein and Berger argue that the expert can determine and should help the court decide which statements by the patient are unreliable. Id. at 390 (citing King v. People, 785 P.2d 596, 602 (Colo. 1990) and WEINSTEIN \& BERGER, supra note 50, at 803-41.

89. Capowski, supra note 52, at 402-04. Professor Capowski recognizes that an argument might be made that the skill of the auditor could produce the traditionally required motivation in the declarant to be honest because the declarant would fear that the expert could discern deception. Id. at 404 . He finds the theoretical basis for that argument inadequate, however.

90. See generally Perrin, supra note 55.

91. Id. at 964-68, 975 (discussing partisanship).

92. Id. at $996-97$.

93. Id. at $964-68$.

94. Id. at 997.

95. Lynne Celander DeSarbo, Comment, The Dangers of Value-Laden Investigation in Child Sexual Abuses Cases: Are Defendants' Constitutional Rights Violated When Mental Health Professionals Offer Testimony Based on Children's Hearsay Statements and Behaviors?, 2 U. PA. J. Const. L. 276 (1999). 
vidual is supportive and not evaluative. ${ }^{96}$ This argument conflicts with Capowski's contention that statements made to those engaged in ongoing treatment of psychological maladies should be admissible. On the other hand, DeSarbo argues that statements made to mental health professionals conducting forensic interviews should often be admissible, but, agreeing with Professor Capowski, she believes they do not fit the medical examination exception. Instead, she contends that such statements should be tested under an ad hoc analysis that depends upon the care and nonsuggestiveness of the interview. ${ }^{97}$ Among the improvements to investigative interviews that she recommends are promptness in conducting the interview and video or audio recording. ${ }^{98}$

Some very provocative theoretical and empirical research by social scientists has been added to this legal analysis. While the research is only in its beginning stages, it suggests that factors generally ignored by legal scholars should be examined because they may be critical to the impact of hearsay upon jurors. Hearsay scholars traditionally focus on credibility of the out-of-court declarant, who is not subject to the traditional evidence-testing techniques of crossexamination, oath, and demeanor, and ignore issues concerning the person who recites the testimony in court. They view the latter as simply not part of a "hearsay problem." W9 With respect to whether such "ear witnesses" heard, remembered, and recited the words uttered out of court with accuracy and truthfulness, hearsay scholars contend their testimony may be tested in the same fashion as any other percipient witness. Social scientists, unsullied by legal theory but interested in the impact and validity of hearsay, find the in-court witness a useful subject of study.

Professors Amye Warren and Cara Woodall conclude from their own empirical research and the work of others that the memory of those reciting hearsay statements is incomplete and selective. ${ }^{100}$ While the gist of the children's statements is preserved by those who hear it, details of the conversation are lost. In particular, the witnesses do not accurately remember the way the information was extracted-the precise questions asked and whether the questions were open-ended or leading..$^{101}$ Professors Warren and Woodall note that, with hearsay statements by children, reliability and the jury's assessment of that reliability depend "first on how accurately and completely the interviewer extracted the information from the child, and secondly, on how accurately and

96. Id. at 278, 298-99. The court in State v. Harris adopted a similar view. 808 P.2d 453, 459 (Mont. 1991)

97. DeSarbo, supra note 95, at 312 .

98. Id. at 316.

99. See 5 WIGMORE, supra note $49, \S 1361$, at 2 (observing that testimony regarding what the witness heard if used to prove only what was heard does not involve a problem of hearsay); see also 4 MUELLER \& KIRKPATRICK, supra note 28, § 370, at 25, 27 (arguing that hearsay focuses on the out-ofcourt speaker and not the witness and that as to the latter the protections of normal courtroom testimony ameliorate dangers associated with hearsay).

100. Amye R. Warren \& Cara E. Woodall, The Reliability of Hearsay Testimony: How Well Do Interviewers Recall Their Interviews with Children, 5 PSYCHOL. PUB. POL'Y \& L. 355, 362-64 (1999).

101. Id. at 365-66. 
completely the interviewer can recollect the interview."102 When relying on memory, the loss of detail about the questioning may lead to errors when admissibility turns on judgments about the type of questioning conducted, and similar concerns should exist regarding the ability of the jury to assess the value of the child's testimony. ${ }^{103}$ Concerns about the quality of the auditor are particularly critical for the medical examination exception, since one prong of the exception depends upon the identity of the auditor as a medical expert. Professors Warren and Woodall's research highlights our ignorance about the ability of these professionals to extract and appraise information and to remember and recount their conversations accurately.

Professor David Ross and his colleagues, confirming expectations, ${ }^{104}$ have found that, in a simulated trial setting, hearsay statements offered by apparently neutral witnesses with professional status, such as a teacher or a doctor, were particularly persuasive to jurors. ${ }^{105}$ Professor Myers and his colleagues conducted a study that provides some context for the role of hearsay testimony in child sexual abuse trials. ${ }^{106}$ In data from forty-two trials held in Sacramento and Phoenix, they found that, except in a single case where only one witness testified, multiple adult witnesses testified to the hearsay statements by the childvictims. ${ }^{107}$ Thus, although hearsay statements were indeed a major component of these trials, these statements did not stand alone. In each case, the child also testified, suggesting that prosecutors are wary of relying solely on the hearsay statements of children. ${ }^{108}$ Finally, although the data do not indicate directly which hearsay exceptions were used, they indicate that the medical examination exception was not widely used in these prosecutions. ${ }^{109}$

\section{B. Supreme Court Developments}

1. Implicit View of Exception in Supreme Court Sexual Abuse Cases. The Supreme Court has decided several cases touching this exception. While resolving some issues directly relevant to application of the exception, the opinions are more suggestive than dispositive. In 1990, the Court decided Idaho $v$.

102. Id. at 356 .

103. See David Dunning, On the Social Psychology of Hearsay Evidence, 5 PSYCHOL. PUB. POL'Y \& L. 473, 474-76 (1999) (noting the impact of lost detail of questions asked and specific content received to admissibility decisions of hearsay and to evaluation of the value of that hearsay if admitted).

104. See Ross et al., supra note 64, at 451-53.

105. Id. at 350-53.

106. See Myers et al., supra note 66.

107. Id. at 396-97.

108. Id. When the child testifies, almost all Confrontation Clause issues are eliminated. See United States v. Spotted War Bonnet, 933 F.2d 1471, 1473-74 (8th Cir. 1991) (noting that the confrontation issue is generally eliminated by putting the declarant on the stand but recognizing that, as to extraordinarily mentally immature children, occasionally a viable issue may remain).

109. Myers et al., supra note 66, at 397 . Although family members occasionally testify to statements under this exception, the two types of professionals most likely to give testimony under it are doctors and social workers. In the study, doctors testified to hearsay statements in only $4 \%$ of cases and social workers in only $3 \%$. Id. 
Wright, which concerned using "particularized guarantees of trustworthiness" to satisfy the requirements of the Confrontation Clause when hearsay is received under an exception that is not "firmly rooted." "The opinion is best known for its determination that such " "particularized guarantees of trustworthiness' ... must ... be drawn from the totality of circumstances that surround the making of the statement and that render the declarant particularly worthy of belief" "111 and not by "evidence corroborating the truth of a hearsay statement." The Court agreed with the Idaho Supreme Court that the prosecution had failed to show that the statements possessed sufficient "particularized guarantees of trustworthiness" required under the Confrontation Clause. ${ }^{113}$

Wright is most interesting for the present topic, however, because it involved statements made by a young child to a pediatrician who was investigating suspected child sexual abuse and because the statements concerned the nature of the abuse and the abuser's identity. After rejecting external corroboration of the truth of the statement as a basis for establishing trustworthiness under the Confrontation Clause, the Court noted with approval some factors identified by other courts that "properly relate to whether hearsay statements made by a child witness in sexual abuse cases are reliable." "These include "spontaneity and consistent repetition," "mental state of the declarant," "use of terminology unexpected of a child of similar age," and "lack of motive to fabricate."

Such ad hoc trustworthiness factors approved by the Court establish an upper boundary for the demands for trustworthiness that may be required of children's statements under the Constitution. If a statement is made under circumstances that would meet the Confrontation Clause's requirement of "particular guarantees of trustworthiness," then it seems both pointless and inappropriate to object to admission of statements for medical diagnosis or treatment under the constitutional rule. The catchall exception provides an alternative route for admission. ${ }^{116}$ The Wright opinion provides an appropriate benchmark for the level of trustworthiness demanded by the Court under the Confrontation Clause.

The case may also suggest what the Supreme Court sees as the reasonable limits of the firmly rooted hearsay exception for statements for medical diagnosis or treatment. This message unfortunately must remain unclear because the factual picture presented to the Court was itself unclear. The case involved al-

110. 497 U.S. 805 (1990).

111. Id. at 820 .

112. Id. at 822 .

113. See id. at 827.

114. Id. at 821.

115. Id. at 821-22.

116. The Court also rejected Wright's argument that the child's incompetency to testify rendered the hearsay either per se or presumptively unreliable, at least absent a finding that incompetency to testify was based on a determination that the child was not "capable of receiving just impressions of the facts and relating them truly." Id. at 824-25. The Court's final point indicates that statements, even by children too young to testify, can be admissible and that the ability to provide testimony at trial is not built into the requirements of the Confrontation Clause. 
legations of abuse against two female children, ages five and one-half and two and one-half, whose parents had separated and were living with other partners. ${ }^{117}$ The older daughter reported to the father's companion that while her mother restrained her, she was raped by the mother's male companion. ${ }^{118}$ The child also stated she had witnessed her younger sister being sexually abused. ${ }^{119}$ The police were notified the next day, and the older child was taken to the doctor, where a medical examination revealed evidence of sexual abuse. ${ }^{120}$ Police and welfare officials took the younger daughter into custody for protection and investigation. ${ }^{121}$ The following day, the younger daughter was examined by the same doctor who had earlier examined her older sister, a pediatrician with extensive experience in child abuse cases. ${ }^{122}$

The litigation focused on the part of the doctor's testimony recounting the statements made by the younger child to him during his examination of her. The doctor testified that the physical examination was "strongly suggestive of sexual abuse with vaginal contact,' occurring approximately two to three days prior to the examination." ${ }^{123}$ The critical portions of the doctor's testimony consisted of the following:

When I asked her "Does daddy touch you with his pee-pee," she did admit to that.... [Although] she would not elucidate ... what kind of touching was taking place.... [s] he did, however, say that daddy does do this with me, but he does it a lot more with my sister than with me.

The trial judge admitted the statement under the state's catchall exception. It is unclear why he did not admit it under the exception for statements for medical diagnosis or treatment. The prosecutor sought admission under both exceptions. ${ }^{125}$ Defense counsel's chief argument against admission was that a statement about the identity of the abuser had no guarantee of trustworthiness either for treatment or for diagnosis of abuse. ${ }^{126}$ After defense counsel made this argument to support the motion to exclude the hearsay, the doctor gave additional testimony in which he stated that the child's statement regarding identity aided his diagnosis that sexual abuse had occurred, but he did not connect the statement to a determination of treatment. ${ }^{127}$ The trial court did not

117. Id. at 808-09.

118. Id. at 809 .

119. Id.

120. Id.

121. Id.

122. Id.

123. Id..

124. Id. at 811 .

125. Joint Appendix at 108, Idaho v. Wright, 497 U.S. 805 (1990) (No. 89-260). The prosecutor cited State v. Bouchard, 639 P.2d 761 (Wash. Ct. App. 1982), which he correctly indicated "held that the attending physician was allowed to testify that a three-year-old child brought to him for treatment of a perforated hymen told him grandpa did it." Joint Appendix at 108.

126. See id. at 109-10. The prosecutor even anticipated the argument about identity in his initial statement about the exception. See id. at 109.

127. He was asked, "Did it help you to know that daddy touched me as opposed to any man touched me or had sexual contact with me? Did the identity of daddy assist your diagnosis in any way?" Id. at 
reference or apparently take note of this testimony that sought to show the pertinence of the statements to the doctor's diagnosis.

In its brief to the United States Supreme Court, the state suggested two additional reasons why admission might be problematic through the medical treatment exception:

[T] he attempt to admit child hearsay statements under the medical treatment exception, Rule 803(4), sometimes runs into problems if the child is too young to understand the doctor-patient relationship or if the interview is conducted by a family pediatrician outside the normal doctor-patient relationship or setting. Unless the court is willing to stretch the usual ground-rules for the medical exception, the hearsay may prove inadmissible. ${ }^{128}$

The trial court did not explain why it did not admit the evidence under the exception for medical examination. Analysis of the text of Idaho's Rule 803(4), its legislative history, and prior and subsequent case law reveals no clear answer to this question. Indeed, whether the exception allowed admission of statements identifying a perpetrator remains unresolved. ${ }^{129}$

Idaho's rule differs slightly from the Federal Rule in that, for the phrase "the inception or general character of the cause or external source thereof" ${ }^{\text {"130 }}$ in the Federal Rule, it substitutes the much briefer phrase "the source thereof." As a result, the word "cause" is omitted. The parties in the Wright litigation, however, ignored this omission or the variation in the rule's wording. The Report of the Idaho State Bar Evidence Committee on the proposed rules, which constitutes the existing legislative history, made no reference to this difference in the rule, and instead tracks the rationale of the Federal Rule, providing only

118. The doctor responded that the fact that a family member may have been involved made it more likely that the cause of the injury was non-accidental trauma because of the increased likelihood of sexual abuse involving a family member. $I d$. at 118-19.

128. Brief for Respondent State of Idaho at 16, Idaho v. Wright, 497 U.S. 805 (1990) (No. 89-260). The first point focuses on the requirement that a child be able to appreciate the purpose of the conversation if the selfish treatment rationale is involved. The second point appears to question whether examination to determine abuse outside of a treatment setting - solely for the purpose of developing evidence-would qualify under the exception. The state cited my 1989 article, inter alia, in its footnote to the final sentence.

129. In State v. Crawford, 716 P.2d 1349 (Idaho Ct. App. 1986), which involved charges that the defendant beat his wife, the intermediate court of appeals stated that "[w]e question whether the identity of the assailant was necessary for the doctor's diagnosis of the injuries." Id. at 1352. In arguing that the admission was erroneous, however, defense counsel pointed not to Idaho law, but instead to federal authority, citing United States v. Narciso, 446 F. Supp. 252, 289 (E.D. Mich. 1977). Brief for Appellant Crawford at 29, State v. Crawford, 716 P.2d 1349 (Idaho Ct. App. 1986) (No. 15791). The state accepted that such evidence was not authorized by the trial court's ruling on the permissible scope of the doctor's testimony. Brief for Respondent State of Idaho at 26, Crawford (No. 15791). Moreover, the Crawford court did not resolve the questions because it found the admission of testimony to be harmless because it was cumulative. Crawford, 716 P.2d at 1352-53. While the facts of Crawford would certainly have been distinguishable under the analysis typified in Renville, and although this authority was not cited by either party in the trial court in Wright, Crawford's questioning of identification evidence's admissibility under the exception may account for the apparent lack of vigor in the prosecutor's argument for admissibility of the statements in Wright under Idaho's Rule 803(4).

130. FED. R. EVID. 803(4).

131. IDAHO R. EVID. 803(4). The rule admits "[s]tatements for the purposes of medical diagnosis or treatment and describing medical history, or past or present symptoms, pain, or sensations, or the source thereof insofar as reasonably pertinent to diagnosis or treatment." Id. (emphasis added). 
the most speculative basis for excluding statements identifying the perpetrator. $^{132}$

The Idaho exception has been construed in a total of five reported cases. ${ }^{133}$ Although none of these cases admit statements identifying the perpetrator, they give no clear answer on whether such statements are ever admissible. ${ }^{134}$ An intermediate appellate court opinion provides the most complete articulation of the standard for admissibility. While the standard does not require a showing that a child was aware of the need to speak truthfully, it sets out a balancing test designed to determine "whether a young child's statement was 'made for the purpose of medical diagnosis or treatment." "135 In a later opinion, the appellate court found that the fact that a statement is made for purposes of discovering evidence to corroborate allegations of sexual abuse should be weighed against admission. ${ }^{136}$ The court clearly does not, however, impose a requirement that treatment be given. ${ }^{137}$

Nothing in the theory or application of Idaho's exception explains why the statements in Wright were not or could not have been admitted under Idaho Rule 803(4). Exactly why the statements were not admitted by the state courts, however, is less significant than the United States Supreme Court's rationale. The Court made two interesting statements. First, in describing why, as to certain exceptions, the declarant's truthfulness is so clear from surrounding circumstances that cross-examination would be of marginal utility, it stated that "the 'dying declaration' and 'medical treatment' exceptions to the hearsay rule are based on the belief that persons making such statements are highly unlikely

132. RePORT OF THE IDAHO STATE BAR EVIDENCE COMMITTEE, C 803, at 6-8. The report makes the same distinction between cause and fault as the Advisory Committee to the Federal Rules, noting that "causation if made for the purposes of diagnosis or treatment" would be admissible under the rule, but "statements as to fault would usually not be." $I d$ at 7 . The only point suggestive of a different analysis as to identifying statements proceeds from the fact that none of the cases cited in the commentary admitted such evidence. Instead, both United States v. Iron Shell, 633 F.2d 200, 204-05 (8th Cir. 1980), and United States v. Nick, 604 F.2d 1199, 1201-02 (9th Cir. 1979), cited by the Committee as relating to the cause-fault distinction, concluded that identity of the abuser was inadmissible. Because of when the report was written, however, selection of cases excluding identifying testimony is much less significant. In 1983, when the report was completed, the landmark cases were just emerging. See, e.g., Goldade v. State, 674 P.2d 721 (Wyo. 1983). Moreover, the report focused on federal law interpreting the Federal Rule, and the groundbreaking federal case admitting identifying evidence, United States $v$. Renville, 779 F.2d 430 (8th Cir. 1985), was still two years away.

133. See State v. Moore, 965 P.2d 174 (Idaho 1998); State v. Zimmerman, 829 P.2d 861 (Idaho 1992); State v. Nelson, 963 P.2d 650 (Idaho Ct. App. 1999); State v. Kay, 927 P.2d 897 (Idaho Ct. App. 1996); State v. Crawford, 716 P.2d 1349 (Idaho Ct. App. 1986). All but Crawford were decided after Wright.

134. Statements by the child regarding the offense were admitted in Moore, but they did not include statements identifying the perpetrator, which the trial court found were not pertinent to diagnosis or treatment. See Brief of Respondent State of Idaho at 18, State v. Moore, 965 P.2d 174, 182-83 (Idaho 1998) (No. 23131) (citing trial transcript at 117). In Nelson, the court affirmatively notes that "Nelson [the defendant] was not identified." Nelson, 963 P.2d at 656.

135. Kay, 927 P.2d at 908. The court cited State v. Dever, 596 N.E.2d 436 (Ohio 1992), as a model for its multi-factored test. For details of the test, see infra note 191.

136. Nelson, 963 P.2d at 655 . The court generally used the term "diagnosis and treatment" but on at least one occasion described it as medical "diagnosis or treatment." Id. (emphasis added).

137. Moore, 965 P.2d at 182-83. 
to lie." ${ }^{138}$ Second, as to the specific statements of the younger daughter admitted by the trial court, the Supreme Court stated that "the statement was not made under circumstances of reliability comparable to those required, for example, for the admission of excited utterances or statements made for purposes of medical diagnosis or treatment." 139

The court did not reveal to which part of the record it was referring when it made those two statements. Absent from the record, however, is any indication that the child, who was only two and one-half years old, appreciated the treatment significance of her statements. ${ }^{140}$ The Court's two statements in Wright are entirely understandable if the Court intended to require something approaching a selfish treatment interest in order for the "medical treatment" exception to be considered firmly rooted. If not, its exclusion of the hearsay turned either on a fluke of state law interpretation or on the Court's ignorance or misunderstanding of the requirements of the exception in Idaho or the facts of the case.

The Supreme Court's decision in White v. Illinois and its underlying facts add both consistency and complication to the picture. ${ }^{141}$ While the discussion below examines the case for its understanding of the trustworthiness of the exception for medical diagnosis or treatment, as in Wright, that issue was not directly before the Supreme Court.

White involved the sexual molestation of a four-year-old child by a friend of the child's mother, who entered the home in the early morning hours while a babysitter was present. ${ }^{142}$ The incident happened at about 4:00 A.M. The child talked to the babysitter almost immediately, to her mother within thirty minutes upon the mother's return home, and to a police officer within an hour. ${ }^{143}$ At approximately 8:00 A.M., she was interviewed by an emergency room nurse, who asked questions to obtain a history to assist her and the attending emergency room physician in making a diagnosis and providing treatment. ${ }^{144}$ In that interview, the child described what happened to her. ${ }^{145} \mathrm{~A}$ few minutes later, and roughly four hours after the sexual abuse, the child spoke with the physician on duty at the emergency room, who also received a history from the patient "for the purposes of making a diagnosis and treating her medically if that was needed." 146 The doctor testified at trial regarding the child's statements to him

138. Wright, 497 U.S. at 820 (citing Mosteller, supra note 2, but not including a parenthetical explanation to indicate agreement or disagreement with the article's principal contentions regarding the basis of the trustworthiness guarantee).

139. Id. at 827 .

140. As noted above, the doctor's testimony did cover why he found the statements relevant to his diagnosis of non-accidental trauma, but he did not indicate that such information was important to psychological or somatic treatment or the appropriate placement of the child. Joint Appendix at 118-19, Idaho v. Wright, 497 U.S. 805 (1990) (No. 89-260).

141. 502 U.S. 346 (1992).

142. Id. at 348 .

143. People v. White, 555 N.E.2d 1241, 1243-44 (Ill. App. Ct. 1990), aff'd, White v. Illinois, 502 U.S. 346 (1992).

144. Id. at 1244.

145. Id. at 1243-44.

146. Id. at 1245 . 
about the abuse and her identification of "Randy," the defendant, as the perpetrator. $^{147}$ While the doctor testified that he put great importance on the history because it was largely the basis for diagnosis, he did not testify that he explained the pertinence of the abuser's identity to diagnosis or treatment. ${ }^{148}$

The trial court admitted the child's statements to all five witnesses under the excited utterance exception and admitted the final two statements to the emergency room nurse and doctor under the state's exception for medical diagnosis or treatment. ${ }^{149}$ The Illinois appellate court affirmed the trial judge's ruling that the first three were admissible under the spontaneous declaration exception and the latter two under the "medical examination exception."

In ruling on the latter two statements, the appellate court applied Illinois's version of statements for the purpose of medical diagnosis or treatment ${ }^{151}$ and imposed no special limitations relating to possible selfish treatment interest by the declarant. ${ }^{152}$ It omitted any discussion of the child's mindset. Rather, the court applied the exception liberally in accord with its perception of general legislative intent and specifically rejected the defendant's argument that statements concerning details of an alleged offense could not be admitted under the exception. The court concluded that the relevant code section "was designed, in part, to sever the artificial restraints heretofore imposed by case law on the ability of a physician to testify about what his or her patient told the physician for purposes of medical diagnosis or treatment." 153 It stated that the relevant section of the "Code evinces a legislative intent that the phrase 'descriptions ... insofar as reasonably pertinent to diagnosis or treatment' should be liberally construed." $" 154$

As in Wright, the United States Supreme Court did not discuss the exception's specific requirements. It described the exception as one "for statements made in the course of ... securing medical treatment," 155 "receiving medical care," 156 and "procuring medical services." 157 The justification for finding that such statements met the requirements of the Confrontation Clause related to the declarant's frame of mind: "[A] statement made in the course of procuring medical services, where the declarant knows that a false statement may cause misdiagnosis or mistreatment, carries special guarantees of credibility that a

147. Id.

148. Id.

149. Id. at 1243-45. See also White v. Illinois, 502 U.S. 346, 351-52 (1992).

150. This is the terminology used, inter alia, by the Supreme Court for the exception. See White $v$. Illinois, 502 U.S. at 351.

151. 115 Ill. COMP. StAT. ANN. 5/115-13 (West Supp. 2000).

152. People v. White, 555 N.E.2d at 1250-51.

153. Id. at 1251.

154. Id. at 1250 .

155. White v. Illinois, 502 U.S. at 350.

156. Id. at 355 .

157. $I d$. at 356. At one point in the opinion, the Court also used the more formal title for the exception "statements made for purposes of medical diagnosis or treatment." Id. at 356 n.8. 
trier of fact may not think replicated by courtroom testimony." ${ }^{58}$ Thus, the Court generally described a trustworthiness rationale that centered on the declarant's motivation, but did not focus on the facts of the case nor deal at all with how those facts might satisfy a rationale centered on the declarant's self-interest.

2. Decisions Construing the Confrontation Clause. A set of Supreme Court decisions concerning the Confrontation Clause that lie outside the child sexual abuse area are also relevant. These cases involve statements against penal interest where the Court has recognized that statements falling within the general category of a long-standing hearsay exception are not necessarily "firmly rooted." ${ }^{159}$ In Lee v. Illinois ${ }^{160}$ the Supreme Court stated that the category of "declaration against penal interest" "defines too large a class for meaningful Confrontation Clause analysis." 161 More recently, in Lilly v. Virginia, the Court held that, despite the fact that Virginia included these statements in its exception for statements against interest and considered the category "firmly rooted," "accomplices' confessions that inculpate a criminal defendant are not within a firmly rooted exception to the hearsay rule as that concept has been defined in our Confrontation Clause jurisprudence."162 The Court noted that Virginia had only recently expanded its exception to include statements against the penal interest of the declarant in criminal trials ${ }^{163}$ and that a number of other states either categorically excluded such statements or restricted their admissibility by following the Supreme Court's limiting principles earlier developed in a federal prosecution. ${ }^{164}$

Before Lilly, the Supreme Court had already solved the Confrontation Clause problem for the federal hearsay exception regarding statements against penal interest. It did so as a matter of evidentiary law analysis in its general efforts to resolve issues of the Confrontation Clause's application to hearsay as a matter of evidence law. ${ }^{165}$ In Williamson v. United States, the Court interpreted the Federal Rules of Evidence to permit admission under the exception only if each individual portion of the statement was in fact against the interest of the declarant. ${ }^{166}$ Thus, the Court effectively defined the federal hearsay exception

158. Id. at 356 .

159. As to "firmly rooted" hearsay exceptions, "[r]eliability can be inferred without more" under the Confrontation Clause. Ohio v. Roberts, 448 U.S. 56, 66 (1980).

160. 476 U.S. 530 (1986).

161. Id. at 544 n.5.

162. 527 U.S. 116, 134 (1999).

163. Id. at $133-34$

164. Id. at $133 \mathrm{n} .4$ (finding that seven states by statute and one by judicial decision categorically exclude such statements, that eight states follow the Supreme Court's decision in Williamson v. United States, 512 U.S. 594 (1994), in limiting the exception, and that three more either have no exception for statements against penal interest or only a very limited exception).

165. See generally 2 MCCORMICK ON EVIDENCE, supra note 15 , § 252, at $126 \mathrm{n} .41$, § 319, at 324-26 (discussing the Court's evidentiary solution in Williamson to Confrontation Clause issue with statements against penal interest).

166. 512 U.S. 594, 600-03 (1994). 
so that any and every statement fitting within it satisfies trustworthiness requirements, because any and every part of such statements must itself carry the trustworthiness guarantee of actually being against the declarant's interest. The redefined and narrowed Federal Rule now constitutes within its full scope a "firmly rooted" hearsay exception. In Lilly, the Court gave notice to the states that either they must reformulate their rules, or any applications outside the "core" would be found unconstitutional under the Confrontation Clause. ${ }^{167}$

Through Williamson and Lilly, the Supreme Court continued along its path of turning Confrontation Clause issues into hearsay issues of evidence rule interpretation and application in the hearsay area. This effort's underlying principle has been that finding an exception to be "firmly rooted" means that a statement within the exception meets the test for trustworthiness "without more," 168 and that if the exception does not theoretically require unavailability of the declarant for admissibility, ${ }^{169}$ the need to show unavailability is eliminated as well. ${ }^{170}$ Thus, in most situations, finding that a statement is admissible as a matter of evidence law also determines that it satisfies the requirements of the Confrontation Clause.

Given that evidentiary errors are reviewed under an abuse of discretion standard ${ }^{171}$ these developments mean that lower court determinations of the key legal issue - admissibility under a hearsay rule-are largely immune from careful appellate scrutiny, even when effectively deciding the constitutional issue as well. The fact that the effective constitutional decision will be made at the trial court level, with appellate courts giving substantial deference, should counsel realism as to any proposed set of uniform trustworthiness requirements. Such a realistic view suggests that broad categories of factors should "count" toward a finding of trustworthiness, and that substantial variance in schemes should be permitted between jurisdictions, as long as some basic level of reliability is achieved.

C. Consensus, Disagreement, and Disintegration in the Lower Courts

The key element of the research in this section involves the treatment of the exception in the lower courts. The analysis of the case law and occasional leg-

167. Lilly, 527 U.S. at 137 . In part, the Court found this limitation to be intended by the rule's somewhat ambiguous language because of the strong historical skepticism of admitting such statements when they implicate someone else, which was the fact pattern at issue in the Williamson case.

168. Ohio v. Roberts, 448 U.S. 56, 66 (1980).

169. Under the Federal Rules, this should include any exceptions listed under Rule 803, where unavailability is irrelevant because the statement in question are at least as trustworthy as what might be obtained through in-court testimony of the declarant. See MCCORMICK ON EvidENCE, supra note 15, $\S 252$, at 124 .

170. Eliminating the requirement of unavailability for admissions and standard exceptions within Federal Rule 803 is the unmistakable import of United States v. Inadi, 475 U.S. 387 (1986), and White v. Illinois, 502 U.S. 346 (1992).

171. An abuse of discretion standard is used by appellate courts to review the trial court's evidentiary rulings. See Gen. Elec. Co. v. Joiner, 522 U.S. 136, 141-42 (1997); Old Chief v. United States, 519 U.S. 172, 174 n.1 (1997); United States v. Abel, 469 U.S. 45, 54 (1984). 
islative developments over the past decade indicates that the most troubling potential misuses of the exception have not occurred, and that frequently the decisions have reflected a real sensitivity to the major trustworthiness concerns. Convictions are reversed in this area with substantial frequency relative to the general reluctance of courts to reverse on evidentiary grounds. ${ }^{172}$ The prong of the exception that admits statements relied upon by experts has not been allowed to operate without constraint in criminal cases. As noted earlier, however, states differ substantially on the substance and the detail of limitations placed on the exception, and for many, the limitations imposed do not prohibit the receipt of hearsay lacking in trustworthiness in several frequently encountered fact patterns. The following analysis concentrates on those states that impose substantial restraints.

1. Limitations Placed on Exception in the States. By the content of their rules, five states have limited the exception to statements made for the purpose of receiving medical treatment and eliminated statements for the purpose of diagnosis from the exception. Thus, statements are excluded if diagnosis is divorced from possible treatment and conducted instead to allow the expert to testify at trial. Louisiana, Maryland, Michigan, Pennsylvania, and Tennessee fall into this category. ${ }^{173}$ Two other states, through judicial applications of the

172. Margaret Berger and Roger Park have noted the relative infrequency of reversals on evidentiary grounds and hearsay grounds respectively. Margaret A. Berger, When, If Ever, Does Evidentiary Error Constitute Reversible Error?, 25 LOY. L.A. L. REV. 893, 894 (1992) (finding in 1990 only thirty reported federal cases that were reversed due to evidentiary error); Roger C. Park, Hearsay, Dead or Alive, 40 ARIZ. L. REV. 647, 648 (1998) (finding that only one out of 220 federal reversals was on hearsay grounds in 1997, down from one in 107 cases for the period from 1960 to 1988). The perception expressed above that reversals occur disproportionately in child sexual abuse cases with respect to evidentiary errors generally is not scientific and is not comparable to the analysis of Berger and Park, since constitutional errors under the Confrontation Clause often trigger the reversal. Nevertheless, it appears that reversals are unusually frequent in child sexual abuse cases.

173. Louisiana's rule reads:

Statements made for purposes of medical treatment and medical diagnosis in connection with treatment and describing medical history, or past or present symptoms, pain, of sensations, or the inception of general character of the cause or external source thereof insofar as reasonably pertinent to treatment or diagnosis in connection with treatment.

LA. R. EVID. 803(4).

Maryland's rule is limited to

Statements made for purposes of medical treatment or medical diagnosis in contemplation of treatment and describing medical history, or past or present symptoms, pain, or sensation, or the inception or general character of the cause or external sources thereof insofar as reasonably pertinent to treatment or diagnosis in contemplation of treatment.

MD. R. EVID. 803(b)(4).

In Low v. State, the court, applying the Maryland rule, concluded that simply because a physician performed the examination and could have provided treatment did not render the statements made to a treating physician. 705 A.2d 67 (Md. Ct. Spec. App. 1998). Rather, the key issue is whether the patient understood that further treatment by the physician was possible. The court concluded that the doctor saw the child for the "sole purpose of examining and detecting child abuse" and was, "in essence, a part of the prosecution team." Id. at 73. It therefore excluded the hearsay under the rule. See also Cassidy v. State, 536 A.2d 666 (Md. Ct. Spec. App. 1988) (establishing the state's restrictive approach to receipt of evidence under the exception).

Michigan's rule covers: 
traditional rationale for the exception, reach similar results: North Carolina, despite a rule identical to Federal Rule 803(4), and Virginia, which has never adopted state rules of evidence. In 2000, the North Carolina Supreme Court held that only statements made for the purpose of obtaining appropriate medical treatment are admissible under its rule 803(4). ${ }^{174}$ The Virginia Supreme Court has also recognized that the rationale for the exception "is that a patient making a statement to a treating physician recognizes that providing accurate information to the physician is essential to receiving appropriate treatment." ${ }^{175}$

Three other states have moved in this same direction by restricting their hearsay rules. Rhode Island's exception explicitly excludes "statements made to a physician consulted solely for the purposes of preparing for litigation or obtaining testimony for trial." 176 South Carolina's rule does not automatically exclude statements made for purposes of litigation, but acknowledges the great significance of that circumstance by giving the trial court the discretion to exclude for that reason. ${ }^{177}$ Vermont's version of Rule 803(4) is much narrower than the federal exception, excluding statements relating to the inception or

Statements made for purposes of medical treatment or medical diagnosis in connection with treatment and describing medical history, or past or present symptoms, pain, or sensations, or the inception or general character of the cause or external source thereof insofar as reasonably necessary to such diagnosis and treatment.

MicH. R. EVID. 803(4).

The Pennsylvania exception admits:

A statement made for purposes of medical treatment, or medical diagnosis in contemplation of treatment, and describing medical history, or past or present symptoms, pain, or sensations, or the inception or general character of the cause or external source thereof, insofar as reasonably pertinent to treatment, or diagnosis in contemplation of treatment.

PA. R. EVID. 803(4).

Tennessee's rule covers "[s]tatements for the proposes of medical diagnosis and treatment describing medical history; past or present symptoms, pain, or sensations; or the inception or general character of the cause or external source thereof insofar as reasonably pertinent to diagnosis and treatment." TENN. R. EVID. 803(4).

174. See State v. Hinnant, 523 S.E.2d 663 (N.C. 2000). The court ruled that " $[\mathrm{t}] \mathrm{o}$ ensure the inherent reliability of evidence admitted under Rule 803(4), we reaffirm our adherence to the common law rationale underlying the rule - that a patient has a strong motivation to be truthful in order to obtain appropriate medical treatment." Id. at 669. Despite this construction of the rule's requirements by the North Carolina Supreme Court, its version of rule 803(4) is identical to the federal rule.

175. Jenkins v. Commonwealth, 492 S.E.2d 131, 134-35 (Va. 1997).

176. Rhode Island's version of the rule provides:

Statements made for the purposes of medical diagnosis or treatment and describing medical history, or past or present symptoms, pain, or sensations, or the inception or general character of the cause or external source thereof insofar as reasonably pertinent to diagnosis or treatment, but not including statements made to a physician consulted solely for the purposes of preparing for litigation or obtaining testimony for trial.

R.I. R. EVID. 803(4).

177. South Carolina admits under this exception:

Statements made for purposes of medical diagnosis or treatment and describing medical history, or past or present symptoms, pain, or sensations, or the inception or general character of the cause or external source thereof insofar as reasonably pertinent to diagnosis or treatment; provided, however, that the admissibility of statements made after commencement of the litigation is left to the court's discretion.

S.C. R. EVID. 803(4). 
cause of the condition. ${ }^{178}$ Moreover, the Vermont Supreme Court made clear that its Rule 703 is not a back door for admission of hearsay. ${ }^{179}$

In addition, Mississippi and New Hampshire require under their rules that, before admitting the statement, the trial judge must affirmatively find that the "statements were made under circumstances indicating their trustworthiness." 180 New Jersey adds a similar, but more modest, requirement that the statement must be "made in good faith." California, which has no general exception for statements for medical diagnosis or treatment, has enacted such an exception for children under the age of twelve who are victims of child abuse or neglect. ${ }^{182}$

178. See State v. Recor, 549 A.2d 1382, 1387 (Vt. 1988). Vermont's rule covers "[s]tatements made for purposes of medical diagnosis or treatment and describing medical history, or past or present symptoms, pain or sensations." VT. R. EVID. 803(4). The Idaho Rule imposes a limitation that might be considered akin to that in the Vermont rule, but on the other hand, its limitation might be nonexistent. Idaho's rule does not include "cause or external source." Instead, it only allows proof of the "source," admitting "[s]tatements made for purposes of medical diagnosis or treatment and describing medical history, or past or present symptoms, pain, or sensations, or the source thereof insofar as reasonably pertinent to diagnosis or treatment." IDAHO R. EVID. 803(4).

179. See Recor, 549 A.2d at 1387.

Although Oklahoma's rule is similar in its coverage to the Vermont rule, its courts have not interpreted the rule to impose similar limitations. Oklahoma's exception covers "statements made for purposes of medical diagnosis or treatment and describing medical history, or past or present symptoms, pain or sensations, if reasonably pertinent to diagnosis or treatment." OKLA. R. EVID. 803(4). In Kennedy $v$. State, the court admitted a statement identifying the perpetrator and describing his abuse made to a pediatrician who was asked to give "a second medical evaluation to further delineate medical findings" several weeks after the abuse was first brought to the attention of the Department of Social Services. 839 P.2d 667, 669 (Okla. Crim. App. 1992). The court imposed the two-part test from Iron Shell and Renville that requires a determination, "was the declarant's apparent motive consistent with receiving medical care," and found that motive satisfied without any affirmative showing of the child's motivation where nothing in the record indicated her motivation "was anything other than for treatment." Id. at 770 .

180. The Mississippi rule covers:

Statements made for the purposes of medical diagnosis or treatment and describing medical history, or past or present symptoms, pain, or sensations, or the inception or general character of the cause or external source thereof insofar as reasonably pertinent to diagnosis or treatment, regardless of to whom the statements are made, or when the statements are made, if the court, in its discretion, affirmatively finds that the proffered statements were made under circumstances indicating their trustworthiness. For purposes of this rule, the term "medical" refers to emotional and mental health as well as physical health.

Miss. R. EVID. 803(4).

New Hampshire's rule allows:

Statements made for the purposes of medical diagnosis or treatment and describing medical history, or past or present symptoms, pain, or sensations, or the inception or general character of the cause or external source thereof insofar as reasonably pertinent to diagnosis or treatment, regardless of to whom the statements are made, or when the statements are made, if the court, in its discretion, affirmatively finds that the proffered statements were made under circumstances indicating their trustworthiness.

N.H. R. EVID. 803(4).

181. The New Jersey rule admits:

Statements made in good faith for the purposes of medical diagnosis or treatment which describe medical history, or past or present symptoms, pain, or sensations, or the inception or general character of the cause or external source thereof to the extent that the statements are reasonably pertinent to diagnosis or treatment.

N.J. R. EVID. 803(4).

182. See CAL. Evid. CODE $\S 1253$ (West 2001). 
The exception follows the language of Federal Rule 803(4), except that it provides that the statement is inadmissible if made under circumstances indicating its lack of trustworthiness. ${ }^{183}$ Florida excludes statements identifying the perpetrator under the hearsay exception for statements made for medical diagnosis or treatment and requires that such statements be analyzed under its special child hearsay exception for statements by children regarding abuse committed against them. ${ }^{184}$ The special exception requires that, at a hearing outside the presence of the jury, the "time, content, and circumstances of the statement provide sufficient safeguards of reliability," which, the Florida Supreme Court recognized, was necessary in order to guard against improper use of the exception for statements for medical diagnosis or treatment. ${ }^{185}$

Another group of states, despite rules that are identical to or strongly resemble the Federal Rule, imposes additional requirements. ${ }^{186}$ New Mexico has a rule identical to the Federal Rule, but appellate case law has observed that statements to doctors for the purpose of testifying have less inherent reliability than statements made to those consulted for treatment. For such non-treating doctors, statements are to be admitted only upon a showing that the statement was given in circumstances with reliability similar to those which exist in a physician-patient relationship. ${ }^{187}$ Montana, which also has a rule identical to the federal rule, allows some flexibility in the types of statements that may be introduced but excludes the most problematic ones. It does not allow extension of the exception "beyond medical doctors in cases involving abuse of young children because we cannot be assured that such statements are 'within the purpose of the exception." "188 It also imposes a two-part test that requires interest in treatment for all statements admitted under the exception: "[S]tatements made for the purpose of diagnosis must first be made with an intention that is consistent with seeking medical treatment and, second, they must be statements that would be relied upon by a doctor when making decisions regarding diagnosis or treatment." 189 Under this test, a statement identifying the abuser was received

183. See id. Section 1253 of the California Evidence Code provides that it is subject to the provisions of Section 1252, which imposes this general requirement relating to trustworthiness. Id. at $\S 1252$.

184. See State v. Jones, 625 So. 2d 821, 824-26 (Fla. 1993).

185. Id. at 823 .

186. In Garrett v. Commonwealth, 48 S.W.3d 6 (Ky. 2001), Kentucky removed itself from this group of states. In Garrett, the Kentucky Supreme Court overruled its decision in Drumm v. Commonwealth, 783 S.W.2d 380 (Ky. 1990), which had required special scrutiny of doctors who provide no treatment. It ruled that the exception applied equally to both examining and treating physicians in line with its interpretation of the Federal Rule 803(4), with which the Kentucky Rules of Evidence were intended to conform. See id. at 12-14.

187. In State v. Altgilbers, 786 P.2d 680 (N.M. Ct. App. 1989), the intermediate court of appeals rejected a requirement that the declarant for admissibility must be shown to have been motivated to seek treatment. In reaching this judgment, the court relied upon Powell's opinion and rationale in Morgan v. Foretich, 846 F.2d 941, 952 (4th Cir. 1988) (Powell, J., concurring), and recognized that, in criminal cases, the approach would require exclusion of some hearsay admissible under the rule by virtue of the requirements of the Confrontation Clause. The court suggested that the approach supported by Powell would usually lead to the same result that I advocated in my 1989 article. Altgilbers, 786 P.2d at 685-86.

188. State v. Harris, 808 P.2d 453, 457 (Mont. 1991).

189. State v. Huerta, 947 P.2d 483, 491 (Mont. 1997). 
when it was made to a treating physician and he or she testified it was helpful for diagnosis and treatment. ${ }^{190}$

Although not substantively different from the Federal Rule, Ohio and Idaho impose a rough totality-of-circumstances analysis on whether statements by children are consistent with the spirit of the treatment-seeking basis of the common law rationale for the rule. ${ }^{191}$ Under its more restrictive rule $1{ }^{192}$ Michigan also uses a totality-of-circumstances analysis when the hearsay involves the abuser's identity. ${ }^{193}$

190. Id. at 490-91.

191. The Ohio Supreme Court in State v. Dever, 596 N.E.2d 436 (Ohio 1992), retreated from what it considered the rigid reliance on the common law's insistence on selfish treatment interest of its earlier decision in State v. Boston, 545 N.E.2d 1220 (Ohio 1989). The court recognized that reliance by an expert was a separate, albeit lesser, basis for admissibility and endorsed the flexible approach of the Michigan Supreme Court in People v. Meeboer, 484 N.W.2d 621, 626 (Mich. 1992). See Dever, 596 N.E.2d at 445. bility:

State v. Kay cited Dever as its model and set out the following factors for determination of admissi-

[W] conclude ... that the trial court should consider the totality of the circumstances surrounding the hearsay statement to determine whether a young child's statement was "made for purposes of medical diagnosis or treatment." The court may consider any factors which bear upon the likelihood that the child made the statement for this purpose, including evidence indicating whether the child understood the need to speak truthfully to the physician and factors that otherwise indicate the reliability of the statements. Circumstances to be considered may include: the child's age; whether the child understands the role of the physician in general; whether the child was suffering pain or distress at the time; whether the child's statements were inappropriately influenced by others, as by leading questions from the physician or a previous suggestive interrogation by another adult; whether the examination occurred during the course of a custody battle or other family dispute; the child's ability and willingness to communicate freely with the physician; the child's ability to differentiate between truth and fantasy in the examination itself and in other contexts; whether the examination was initiated by an attorney (which would suggest that its purpose was for litigation rather than treatment); and the timing of the examination in relation to the trial. If the trial court finds that the foregoing factors, and others reasonably related to the inquiry, give little reason to doubt the child's motivation, the court may infer that the criteria of I.R.E. 803(4) are met.

927 P.2d 897, 908 (Idaho Ct. App. 1996).

192. See 2 MCCORMICK, supra note 165 .

193. See State v. Meeboer, 484 N.W.2d 621 (Mich. 1991). The court specified that, for admissibility under the rule, "these statements [of identity] must also be made with the understanding by the declarant of the need to tell the truth to the physician." Id. at 630. To make that critical determination it set out ten factors:

While the inquiry into the trustworthiness of the declarant's statement is just one prong of the analysis under MRE 803(4), it is very important that the understanding to tell the truth to the physician be established. Factors related to trustworthiness guarantees surrounding the actual making of the statement include: (1) the age and maturity of the declarant, (2) the manner in which the statements are elicited (leading questions may undermine the trustworthiness of a statement), (3) the manner in which the statements are phrased (childlike terminology may be evidence of genuineness), (4) use of terminology unexpected of a child of similar age, (5) who initiated the examination (prosecutorial initiation may indicate that the examination was not intended for purposes of medical diagnosis and treatment), (6) the timing of the examination in relation to the assault (the child is still suffering pain and distress), (7) the timing of the examination in relation to the trial (involving the purpose of the examination), (8) the type of examination (statements made in the course of treatment for psychological disorders may not be as reliable), (9) the relation of the declarant to the person identified (evidence that the child did not mistake the identity), and (10) the existence of or lack of motive to fabricate.

$I d$. at 627. As noted earlier, the Michigan evidence rule limits scope of the rule to "[s]tatements made for the purposes of medical treatment or medical diagnosis in connection with treatment." See 2 
As a related limitation, a number of state courts have refused to allow the exception for statements for medical diagnosis or treatment to be applied to groups other than medical doctors. Frequently, these are jurisdictions that have limited the exception's general scope, but sometimes this restriction stands alone. Courts in Idaho, Michigan, and Tennessee hold that statements to psychologists are not admissible under Rule 803(4), because psychologists do not provide medical care within the meaning of the exception. ${ }^{194}$ Louisiana and $\mathrm{Ne}-$ braska courts have expressed special concerns about such testimony. ${ }^{195}$ Connecticut, Kentucky, and Wisconsin specifically refuse to extend the exception to statements made to social workers and "counselors." 196 Texas excludes statements to social workers acting as investigators. ${ }^{197}$ Finally, as noted above, Montana restricts the exception to medical doctors when young children are involved. ${ }^{198}$

The treatment of the statements for the medical examination exception clearly varies in important respects in the jurisdictions discussed above, and some states exhibit some continuing troubling elements. ${ }^{199}$ These states generally, however, have moved toward a moderate and largely satisfactory point in examining motivation and circumstances for evidence of trustworthiness. The analysis shows that a considerable number of states impose requirements beyond what is required by a liberal application of the Federal Rule's language.

MCCORMICK, supra note 165. Under this analysis, the court in Meeboer found that statements from the children in two cases were admissible. See Meeboer, 484 N.W.2d. at 630-32. It excluded those in a third case, however, because of the child's young age and the passage of several weeks between the alleged abuse and the second examination when the statements were made. Id. at 632-33.

194. See, e.g., State v. Zimmerman, 829 P.2d 861, 864 (Idaho 1992); State v. LaLone, 437 N.W.2d 611, 612-13 (Mich. 1989); State v. Barone, 852 S.W.2d 216, 219-20 (Tenn. 1993).

195. In State v. White, the Nebraska Supreme Court concluded that, at least in the case at hand, statements to psychiatrists should not be received under the rule as a conduit for hearsay from a competent witness. 507 N.W.2d 654, 658 (Neb. 1993). In addition, the intermediate court of appeals in Louisiana has concluded that statements to psychiatrists should not be received because of the skewing influence of the condition under treatment and the scope of the statements covered, or at least, admission in such situations should be subject to judicial discretion to exclude for these reasons. See State v. Carter, 762 So. 2d 662, 676 (La. Ct. App. 2000).

196. See State v. Cruz, 746 A.2d 196, 200 (Conn. App. Ct. 2000) (ruling that the "treating physician's exception" does not cover statements to social workers, except if the social worker is acting as a conduit for information for a physician); State v. Barile, 738 A.2d 707, 712-13 (Conn. App. Ct. 1999) (excluding a statement because it was made to a social worker and not a physician); Sharpe v. Commonwealth, 849 S.W.2d 542, 546 (Ky. 1993) (finding statements to social workers inadmissible); State v. Huntington, 575 N.W.2d 268, 278 (Wis. 1998) (declining to apply the exception to statements to counselors or social workers).

197. See Gohring v. State, 967 S.W.2d 459, 462-63 (Tex. Ct. App. 1998) (holding that statements "are not admissible in the case of a social worker employed as a child abuse investigator unless there is a showing both that there is a medical care component to the worker's employment and that the declarant is aware of that medical care component").

198. See State v. Harris, 808 P.2d 453, 457 (Mont. 1991) (excluding statements made to unlicensed counselor); State v. J.C.E., 767 P.2d 309, 313 (Mont. 1989) (excluding statements made to social worker and counselor).

199. For example, some states use the standard of Morgan v. Foretich, 846 F.2d 941, 952 (4th Cir. 1988) (Powell, J., concurring). See, e.g., Drumm v. Commonwealth, 783 S.W.2d 380, 385 (Ky. 1990), discussed supra note 186. Morgan uses a balancing test that generously favors admissibility. Others, instead of demanding an affirmative showing of trustworthiness, are satisfied if untrustworthiness is not clearly shown. See Kennedy v. State, 839 P.2d 667 (Okla. Crim. App. 1992), discussed supra note 6. 
2. Treatment of the Exception in the Lower Federal Courts. Like the states, federal courts also vary in their interpretation of the exception. Although the language of Federal Rule 803(4) covers statements given either for diagnosis or for treatment, in a number of courts the test for admissibility turns this disjunctive test-diagnosis or treatment-into a modified conjunctive analysis-effective diagnosis and treatment. The two-part conjunctive test arose in the Eighth Circuit case United States v. Iron Shell ${ }^{20}$ and was spread by its use in the frequently cited United States v. Renville. ${ }^{201}$ In Iron Shell, the court noted that "two independent rationales support the rule" and considered both "helpful in its application." ${ }^{202}$ From these rationales, it created a "two-part test": "first, is the declarant's motive consistent with the purpose of the rule; and second, is it reasonable for physicians to rely on the information in diagnosis or treatment."203

As my earlier article suggests, ${ }^{204}$ this conjunctive test confounds the Federal Rule's disjunctive wording but might serve to eliminate potential difficulties with the Confrontation Clause. The Eighth Circuit explicitly recognized the link between satisfying the Confrontation Clause and the declarant's interest by invoking the Supreme Court's treatment of the exception in White. ${ }^{205}$

After leading the development of an expanded exception, the Eighth Circuit in recent years has begun to emphasize the requirement that the declarant's motivation must be consistent with the Rule's purpose and thereby has limited application of the exception, particularly when statements by young children are involved. In 1999 and 2000, this circuit reversed three cases because the child did not understand that the statements relating to the assailant's identity and actions were consistent with the purpose of promoting treatment. ${ }^{206}$

200. 633 F.2d 77 (8th Cir. 1980).

201. 779 F.2d 430 (8th Cir. 1985).

202. 633 F.2d 84 .

203. Id. In looking for motivation consistent with the rule's purpose, the court focused on the child's motive for "seeking treatment." Id. See also Renville, 779 F.2d at 436.

204. See Mosteller, supra note 2, at 277.

205. The principal reason why 803(4) is a traditional hearsay exception automatically carrying the indicia-of-reliability label is because of the selfish-motive doctrine. This exception is based on the belief that a person seeking medical treatment is unlikely to lie to a doctor she wants to treat her, since it is in her best interest to tell the truth.

Ring v. Erickson, 983 F.2d 818, 820 (8th Cir. 1993) (citing White v. Illinois, 502 U.S. 346, 354-56 (1992)). The Fourth Circuit also adopted this two-part test. See Morgan v. Foretich, 846 F.2d 941, 949 (4th Cir. 1988) (quoting Renville, 779 F. 2d at 436). The circuit is far better known, however, for the balancing test applied in criminal cases developed by Justice Powell sitting by designation. See id. at 952 (Powell, J., concurring).

206. See United States v. Sumner, 204 F.3d 1182, 1184-86 (8th Cir. 2000) (reversing the conviction because the doctor failed to discuss with the six-year-old victim why it was important for the child to be truthful regarding the identity of the abuser, the medical significance of being truthful, and the role of the medical professional in helping her, which would trigger the motivation to be truthful); United States v. Beaulieu, 194 F.3d 918, 920-21 (8th Cir. 1999) (reversing the conviction because the child's testimony showed that she understood the purpose of her visit to the nurse and psychologist as "just to get evidence," and therefore the statements of identity were inadmissible because the purpose was not consistent with promoting treatment); Olesen v. Class, 164 F.3d 1096, 1097-98 (8th Cir. 1999) (reversing the conviction because the Confrontation Clause was violated where the state failed to prove that a fiveyear-old child had a motive in making the statement consistent with promoting treatment and that she understood the medical significance of being truthful in identifying her abuser). 
Similarly, the Ninth Circuit has required an interest in treatment under the exception. In this analysis, the court relied on the Supreme Court's terminology and apparent trustworthiness rationale used in White. ${ }^{207}$ It also rested its analysis on citations to the exception's traditional common law basis that the patient's strong motivation is to be truthful. ${ }^{208}$

The Tenth Circuit takes a different theoretical view. It rejects the requirement that a court inquire into the child's motivation. ${ }^{209}$ Instead, also relying in part on White, it finds trustworthiness guarantees in the context of the child receiving medical services. ${ }^{210}$ In United States $v$. Tome, ${ }^{211}$ after remand of a case for violating restrictions on the admission of prior inconsistent statements ${ }^{212}$ the Tenth Circuit ruled that statements made by the child to three different pediatricians were properly admissible under the medical examination exception, because the statements were relevant to the doctors' diagnosis. ${ }^{213}$ In contrast to White, however, some of these conversations were not close in time to the injuries nor to the initial medical examination and potential treatment of any injuries. ${ }^{214}$ On the other hand, the court did exclude statements made to a case-

207. See People of Guam v. Ignacio, 10 F.3d 608, 612 (9th Cir. 1993) (quoting White's use of "statements made in the course of receiving medical care" terminology, 502 U.S. at 355, and adopting a trustworthiness rationale to support its "firmly rooted" status that "[t]he basis for this exception is the presumption of reliability of statements which flow from 'the patient's strong motivation to be truthful," Ignacio, 10 F.3d at 612 (quoting FED. R. EVID. 803(4) advisory committee's note)). In analyzing the issue, the circuit court appeared to base its view of the trustworthiness rationale on the Court's statements in White. See id. at 612-13.

208. See Ignacio, 10 F.3d at 612-13 ("The rationale for the exception is that the patient can be expected to tell the truth about her injury because she will want to be diagnosed correctly and treated properly."). Under its analysis, statements were admitted when made to a doctor during his examination of injury to the child's vaginal area, but not when made to a social worker seeking information to determine whether to notify Child Protective Services about a case of possible child abuse. The court considered the latter statement to be related to ensuring the child's safety, not treatment. See id. at $610-11,613$. It also noted that under the "medical treatment exception," admissibility depends not only on the intent of the person asking the questions but also on "whether the respondent understands herself to be providing information for purposes of medical treatment." Id. at $613 \mathrm{n} .3$; see also Webb v. Lewis, 44 F.3d 1387, 1390-91 (9th Cir. 1994) (finding that a videotaped statement made to a social worker to determine whether the child had been abused was not within the exception because it was not therapeutic and thus not a medical procedure).

209. See United States v. Joe, 8 F.3d 1488, 1495 n.5 (10th Cir. 1993).

210. See United States v. Norman T., 129 F.3d 1099, 1105 (10th Cir. 1997) ("Without discussing the issue of age, the [Supreme] Court [in White] upheld the admission of statements made by a four-yearold abuse victim to a doctor because statements made when procuring medical services 'carr[y] special guarantees of credibility"' (quoting White, 502 U.S. at 356)); Joe, 8 F.3d at 1494 n.5 (holding that the context of a statement that is built into the rule's requirements assures trustworthiness); see also United States v. Pacheco, 154 F.3d 1236, 1240 (10th Cir. 1997) (ruling that there is no presumption that the rule is inapplicable to a child's statement because young children may not understand the importance of telling the truth to a doctor, although noting that the defendant failed to point out any evidence that the child did not understand).

211. 61 F.3d 1446 (10th Cir. 1995).

212. See United States v. Tome, 513 U.S. 150 (1995).

213. Tome, 61 F.3d at 1449-51. Judge Holloway dissented from the ruling that the statements of these doctors were admissible because insufficient evidence indicated that the child appreciated the importance of telling the truth and thus the statements failed to satisfy the selfish treatment interest rationale of the rule. Id. at 1458 (Holloway, J., dissenting).

214. From the point of view of being divorced from treatment, the most troubling statement was made to Dr. Jean Spiegel, an assistant professor of pediatrics at the University of New Mexico, who 
worker from Protective Services who said her interview was for the purpose of determining whether a protective order was necessary, not for diagnosis or treatment. ${ }^{215}$

The Seventh Circuit has adopted what is potentially the most expansive approach to admissibility. Because of the limited number of cases decided in the circuit under the exception, however, it is not clear whether this theory would extend fully to criminal cases. In a civil case, the court noted that the exception covered both statements made for treatment and for diagnosis, adopting Judge Weinstein's view that the test for admissibility of statements for diagnosis is the same as under Federal Rule 703: whether the particular fact is one that an expert would be justified in relying upon in rendering an opinion. ${ }^{216}$ Its only clear application in a criminal case involved statements made to a treating physician. $^{217}$

\section{$\mathrm{V}$ \\ DISCUSSION AND GENERAL ANALYSIS}

\section{A. Auditors' Skill Provides an Inadequate Basis for Hearsay Admission}

The academic commentary, Supreme Court decisions, trends in evidence law, and a rich array of lower court analysis and rulemaking activities provide the raw material for making some judgments about the medical examination exception a quarter century after the enactment of the Federal Rules. Most commentators, and occasionally courts, are disquieted by basing hearsay admissibility on the skill of those who hear the statements-the auditors. In the decade since my earlier article, no additional arguments have been developed for why the reliance of medical professionals should be sufficient for admission. Except as a simplification of the law and a housekeeping change for civil cases, which likely was the drafters' perception of what proved to be their most significant modification of the exception, the justification for the change in the exception has not been explained, and a viable general rationale for admitting important hearsay based on the auditor's expertise is simply lacking.

The commentators find the diagnosis-only rationale a unique basis for admission of hearsay. They also note the concern, long recognized in evidence

conducted her interview approximately one year after the other doctors and two years after the alleged abuse. See United States v. Tome, 3 F.3d 342, 346 (10th Cir. 1993). The court described the purpose of her interview as giving a second opinion on whether the child had been sexually abused. See id. at 1451.

215. See id.

216. See Gong v. Hirsh, 913 F.2d 1269, 1273 n.4 (7th Cir. 1990). For a discussion of Judge Weinstein's position, see supra note 50 and accompanying text.

217. See United States v. Cherry, 938 F.2d 748, 756-57 (7th Cir. 1991). Because the child testified and was subject to cross-examination, the court noted that no Confrontation Clause issue was presented by applying the rule to admit such statements. Therefore, it did not face the issue raised in an earlier case whether special constitutional scrutiny ought to apply when the exception covered statements exceeding the scope of its traditional common law formulation. See id. at $757 \mathrm{n} .18$ (citing an argument made by Judge Flaum in Nelson v. Farrey, 874 F.2d 1222, 1234 (7th Cir. 1990) (Flaum, J., concurring)). 
law and motivating recent restrictions on expert testimony, that the nature of the interviewer's skill is subject to bias by adversarial motivation when an expert is selected to develop evidence for trial. ${ }^{218}$

Admission of this hearsay based on the skill of the auditor runs contrary to the principal theory of hearsay trustworthiness. Wigmore's view of the basis for hearsay exceptions ${ }^{219}$ was adopted by Wright as the theory for why firmly rooted exceptions require no further testing by cross-examination. ${ }^{220}$ As presented by the Court, the justification for receiving the out-of-court statement in the absence of an opportunity to cross-examine the declarant rests on factors such as the declarant's motivation and the circumstances of the statement. These factors make the speaker particularly worthy of belief and render crossexamination of marginal utility. ${ }^{221}$ Thus, the principal accepted theory does not permit basing admission of hearsay on the skill and training of the auditor. ${ }^{222}$

The broad trends in evidence law are also inconsistent with basing admission on the auditor's skill. Daubert and Kumho Tire show a commitment to screening unreliable expert evidence from the finders of fact. Under these tests, psychologists, psychiatrists, and social workers would almost certainly be prohibited from testifying to their opinion that a child was abused based on conversations with the child. While doctors could make such determinations based

218. At first blush, the effect of the auditor's bias might be seen as properly going only to weight and credibility, rather than to admissibility. With respect to defining the characteristics of a hearsay exception, however, those for "business records," FED. R. EVID. 803(6), and governmental records, FED. R. EVID. 803(8)(B) \& (C), provide clear support for treating motivational bias generated by the adversarial process as a basis for exclusion rather than simply diminished evidentiary value. In both rules, the judge is given discretion to exclude the statement based on bias as one of the "circumstances of preparation [that may] indicate lack of trustworthiness." FED. R. EVID. 803(6) \& 803(8) advisory committee's note (discussing Palmer v. Hoffman, 318 U.S. 109 (1943)).

219. See 5 Wigmore, EVIDENCE supra note 49, § 1420, at 251.

220. See Wright, 497 U.S. at 819.

221. See id. at 819-20. In adopting Wigmore's rationale and limiting excluding consideration of external corroboration from the trustworthiness analysis, the Court stated:

[W] think the relevant circumstances include only those that surround the making of the statement and that render the declarant particularly worthy of belief. This conclusion derives from the rationale for permitting exceptions to the general rule against hearsay... [here quoting Wigmore's rationale]. In other words, if the declarant's truthfulness is so clear from surrounding circumstances that the test of cross-examination would be of marginal utility, Id. then the hearsay rule does not bar admission of the statement at trial.

222. Recent research showing that auditors generally do not accurately remember the details concerning how a particular statement was developed, such as the questioning technique used, adds to doubt about relying on the auditor's skill to justify admission of the statement. See supra text accompanying notes 100-104. Medical professionals might possess the skill and facilities to observe and record information about the manner in which statements are elicited, but it is far from clear that their professional training sensitizes them to these problems, particularly when they are part of an investigative team motivated to uncover and prosecute abuse. Indeed, even the best trained interviewers do not record accurately details about the manner in which information was received. See Michael E. Lamb et al., Accuracy of Investigators' Verbatim Notes of Their Forensic Interviews with Alleged Child Abuse Victims, 24 LAW \& HUM. BEHAV. 699, 704-05 (2000) (noting that, even when experienced interviewers made contemporaneous verbatim notes of interviews with children, the interviewers' role in eliciting information was understated). 
mostly on physical examinations, neither doctors nor psychologists nor social workers would be permitted to give an opinion on the perpetrator's identity. ${ }^{223}$

The Federal Rules Advisory Committee has determined that the original standard in the Federal Rules for placing before the jury inadmissible evidence supporting the expert's opinion was too lax. Rather than receiving such inadmissible evidence subject to the strictures of Rule 403, the new rule requires that the evidence only be admitted when its prejudicial impact is substantially outweighed by its probative value to evaluate the expert's opinion. ${ }^{224}$

In a recent article about revised Rule 703, Professor Ronald Carlson brought together a number of changes in the law that cumulatively cut the foundation from under the diagnosis-only prong of Rule 803(4). ${ }^{225}$ At the time the rules were promulgated, a "let it all come in" attitude existed with respect to experts who "were viewed as impartial specialist[s] who came to trials to explain technical concepts to triers of fact."226 Now the courts have recognized the proliferation of unsound experts who advocate for the side that hired them and have emphasized a need to ensure admission of only valid evidence. ${ }^{227}$

The principal justification given for substantive admissibility of hearsay statements to diagnosis-only experts was that the evidence would be heard anyway to support the opinion of the expert, and jurors would not be able to follow the limiting instructions. ${ }^{228}$ Now, under revised Rule 703, the inability of the jury to understand and follow a limiting instruction is generally recognized instead as a reason to be cautious in allowing jurors to hear the inadmissible evidence in the first place. ${ }^{229}$ Taking these changes into account, there is a much weaker theoretical basis for receiving statements made for diagnosis only than

223. While experts cannot discern whether a witness is testifying truthfully as a general matter, some experts claim that it is possible to assess the truthfulness of sexual abuse allegations even when not based on physical evidence. See C.L. Ruby \& John C. Brigham, The Usefulness of the Criteria-Based Content Analysis Technique in Distinguishing Between Truthful and Fabricated Allegations: A Critical Review, 3 PSYCHOL. PUB. POL'Y \& L. 705 (1997) (describing the Criteria-Based Content Analysis technique and concluding that the experimental studies do not establish its validity in assessing truthfulness); see also David C. Raskin \& John C. Yuille, Problems in Evaluating Interviews of Children in Sexual Abuse Cases, in Perspectives On ChILdREN's Testimony 184-207 (Stephen J. Ceci et al. eds., 1989). Whether the techniques used can be validated so that they will satisfy Daubert and Kumho Tire remains to be seen. Extending such validation to statements identifying the perpetrator presents another level of challenge.

If experts are able to make such assessments of truth, there would be a basis in the skill of the auditor to receive hearsay statements, although, even then, the exception would not be "firmly rooted" under Confrontation Clause analysis. It would have a valid theoretical basis in trustworthiness analysis, albeit a new type of trustworthiness analysis, unlike the current state of Rule 803(4).

224. See FED. R. EVID. 703.

225. See generally Ronald A. Carlson, Is Revised Expert Witness Rule 703 a Critical Modernization for the New Century?, 52 FLA. L. REV. 715 (2000).

226. $I d$. at 744 .

227. See id. at 740-41, 744 .

228. See FED. R. EVID. 803(4) advisory committee's note.

229. Carlson, supra note 225, at 736-37. 
when the Federal Rules were drafted, and legislatures and courts should consider reformulating and narrowing the Rule. ${ }^{230}$

Certainly under the more rigorous standard, admission of statements identifying a perpetrator of an offense is unjustified. As noted above, many experts, including psychologists, psychiatrists, and social workers, cannot testify even as to an opinion that the offense was committed, and no expert, not even a physician, is permitted to testify to an opinion as to the abuser's identity. Admission of such hearsay has significant consequences. Sometimes it stands alone or constitutes a major piece of the evidence on a highly disputed issue. Its admission could not be treated as insubstantially prejudicial, particularly since counterbalancing probativity to support the opinion is entirely lacking. Thus, Rule 703 would clearly prohibit receipt of the hearsay as to the perpetrator's identity. For all of these reasons, admitting evidence on the basis of the auditor's skill should not be tolerated in criminal cases and where, as in child sexual abuse cases, the hearsay often is both critically important and potentially accusatory in nature.

\section{B. Proposed Minimal Requirements for Admission under the Confrontation Clause}

Regardless of what happens regarding reform of the scope of the exception, the facts of Wright, where "the statement was not made under circumstances of trustworthiness comparable to those required ... for statements made for purposes of medical diagnosis or treatment," ${ }^{231}$ and those of White, where the exception was satisfied, suggest the minimal requirements for admission. Wright involved an interview with a very young child with no indication that she understood the interview's significance as it related to her medical health. ${ }^{232}$ The interview was not conducted in the immediate aftermath of a caretaker's discovery of potential abuse. Instead, it was part of an investigation of suspected child abuse by a doctor who was part of an investigative team, questioning the child in a manner that suggested his prosecutorial role. ${ }^{233}$

The child in White, while still quite young, was a few years older than the child in Wright and might more easily have understood the significance of the examination, but the facts reported in neither the state appellate court nor the Supreme Court reflect such an appreciation. ${ }^{234}$ The examination, however, was

230. Several states have already defined their exception to admit only statements made with a view to treatment. See supra notes 165-183 and accompanying text.

231. Wright, 497 U.S. at 827.

232. See supra notes $114-140$ and accompanying text. As set out in the earlier discussion, (1) the child, who was two and one-half at the time of the incident, did not testify at trial and was ruled incompetent; (2) the testifying doctor gave no basis on which to find that the child understood the treatment significance of her statements; and (3) the State made no claim in its briefs that the child understood the treatment significance and indeed suggested the opposite in arguing for the need to allow admission under the catchall exception. See id.

233. State v. Wright, 775 P.2d 1224, 1227 (Idaho 1989) (questioner had "preconceived idea of what the child should be disclosing").

234. See discussion of White, supra notes 142-158 and accompanying text. 
made promptly upon discovery of the apparent abuse $\mathrm{e}^{235}$ and was conducted by a doctor at the local emergency room. ${ }^{236}$ The information came from a medical examination, not an investigative interview to find or confirm sexual abuse as part of a prosecutorial team.

From these cases, one can draw a rough scheme for admission and exclusion of statements in some common scenarios. If no showing is made of the child's appreciation of the treatment purpose of the examination and interview, circumstances must be found to indicate that its basic character related to treatment. When the interview is conducted as part of a bona fide medical examination, fine-tuning regarding the precise content of each statement is not required. When a statement is made to an investigative team member, even if a medical doctor, the admission of hearsay should be further scrutinized.

\section{Reasonable Approaches Used by Some Courts}

Many courts and legislatures appear to be searching for a way to eliminate the danger that this exception will become a major pathway for accusatory hearsay. The paths are quite variable and proceed through rule revision, judicially mandated trustworthiness requirements, or imposition of constitutional restrictions. The more rigorous tests require a showing of selfish treatment interest and prohibit using the exception in the absence of a care-giving relation$\operatorname{ship}^{237}$ and/or once primary care has been received. ${ }^{238}$ Other states use balancing tests or multi-factored tests that look positively for suggestions of trustworthiness in the motivation of the speaker and the circumstances of the interview and negatively for factors indicating manipulation or motivational problems by those seeking the statements. ${ }^{239}$ Given what the Supreme Court has implicitly blessed in White and condemned in Wright, not much more can be required as a matter of constitutional law, and all of these approaches meet this constitutionally required level of basic trustworthiness. ${ }^{240}$

235. As noted earlier, the abuse occurred and was discovered at approximately 4:00 A.M. and the examination was conducted shortly after 8:00 A.M., just over four hours later, on the same morning. See text accompanying notes $135-136$.

236. Id.

237. See Low v. State, 705 A.2d 67, 72-73 (Md. Ct. Spec. App. 1998).

238. In construing the requirement of "medical pertinency," the court stated that, "[i]f the declarant is no longer in need of immediate medical attention, the motivation to speak truthfully is no longer present," and on that basis, it excluded a statement made to a clinical psychologist two weeks after initial medical treatment. State v. Hinnant, 523 S.E.2d 663, 670-71 (N.C. 2000). The court's general instinct to limit medically pertinent statements to a treatment setting is sound, although its relatively wooden application of the principle is likely to be too inflexible.

239. For a discussion of some of the states using this multi-factored approach, see supra note 6 and accompanying text.

240. The developments in a number of states restraining the scope of the exception and the reversal of a substantial number of cases is, in many ways, counter to a general trend of tough-on-crime judicial rulings during the last quarter of the century. It seems that the major scenarios where the exception might have been broadly used as a conduit for admission of hearsay have not developed. Part of the reason for the restraint has likely been growing skepticism of abuse allegations in the wake of the daycare prosecutions of the 1980s and the generally developed view that questionable investigative efforts by psychologists and social workers with preconceived notions of guilt were substantially to blame for 
As noted above, if the expert is not allowed to testify with regard to an opinion, the rationale that allows admission of statements because the jury would hear them in any event to support the opinion is inapplicable and invalid. When this problem has been examined directly, such a restriction is adopted, ${ }^{241}$ and courts do not admit statements to non-medical experts unable either to treat conditions or to render admissible opinions. This result, which might be seen as flowing more directly from the use of the term "medical" in the exception, fortunately has meant that some of the more inappropriate accusatory statements have been avoided.

\section{A Most Troubling Scenario}

Despite rejecting an explicit extension of the exception to experts who are only diagnosing non-medical conditions as to which they can render no opinion, statements are routinely admitted when made to medical doctors, where the expert is prohibited from testifying to the conclusion reached from the statement and where no treatment is anticipated. A medical doctor may consider the identity of the abuser relevant to treatment of the child. Thus, in theory, the statement can be received. That doctor, however, is not permitted to give an opinion as to the abuser's identity. Nevertheless, in many jurisdictions, medical doctors who have been consulted solely for the purpose of diagnosis with no treatment anticipated may testify regarding statements identifying the abuser. I believe this result is erroneous.

A typical and troubling scenario, as described in the hypothetical at the beginning of this essay, involves a pediatrician examining and interviewing a child for initial examination and treatment as part of a "second opinion" to determine whether abuse had occurred. ${ }^{242}$ This situation provides clear opportunity for the prosecution to select the doctor, regardless of technical skill, for a specific purpose - as a member of the prosecution team to secure helpful accusatory statements. ${ }^{243}$ The fact that the expert is a physician does not alone provide

overreaching. Whatever the reason, the typical reported case involves either conversations that occurred quite quickly after the episode with treating doctors or in limited-duration interviews with investigative team members somewhat later. Cases in which hearsay evidence is offered from interviews by experts with esoteric expertise, where the exception would be operating as nothing other than a ploy to receive hearsay, are rarely seen.

241. See United States v. ex rel. Wetterer, 991 F. Supp. 112, 121 (E.D.N.Y. 1998). See also 4 MUELLER \& KIRKPATRICK, supra note 28, § 442, at 457 (agreeing that such a limitation should be imposed). But see State v. Nelson, 406 N.W.2d 385, 392 (Wis. 1987) (rejecting the argument that an opinion must be rendered where the court concluded that the child had a selfish interest in treatment), aff'd, Nelson v. Farrey, 874 F.2d 122 (7th Cir. 1990).

242. See supra notes 2-4.

243. Margaret Berger has argued that the Confrontation Clause is primarily intended as a restraint on the use of government power in creating evidence through private interviews. See Margaret A. Berger, The Deconstitutionalization of the Confrontation Clause: A Proposal for a Prosecutorial Restraint Model, 76 MinN. L. REV. 557, 560-62 (1992). Although the Court has clearly not adopted this view as an organizing principle, when a version of the type of practice Berger believes offends the Constitution was presented in a relatively pure form in Lilly v. Virginia, 527 U.S. 116 (1999), which involved government interrogation of a co-defendant, the Court found the practice constitutionally invalid. Whatever is the emphasis of the confrontation right, a central component of the Confrontation Clause 
a guarantee of trustworthiness to justify receiving the child's statements under a hearsay exception. ${ }^{244}$ Something more to support trustworthiness should be required.

\section{E. Proposed Solution}

Assuming that a fundamental and widespread revision of the exception that requires a selfish treatment interest to be shown for all declarants does not occur, examining the theory of admissibility for identification of the abuser gives guidance on the types of more narrowly tailored, specific restraints that should be imposed. If a doctor, or psychologist/psychiatrist, is actually treating or expecting to treat a child, the statement of the child that identifies the perpetrator may have implications for treatment. Thus, it has important medical pertinency and provides some urgency for the expert to work diligently to establish its accuracy. In addition, admitting such statements may be justified by the child's perception of a selfish treatment interest in being accurate as well.

Admission of statements regarding identity may be acceptable when made to doctors involved in the treatment of the child, either under the theory that the child has a selfish treatment interest that guarantees trustworthiness, or on a more general theory that statements made to physicians involved in treatment not long after the incident generally have adequate trustworthiness because they are (1) reasonably contemporaneous with the abuse or its discovery, (2) often not adversarial, and (3) intermeshed with statements obviously related to physical well-being. When the medical doctor is offering a second opinion separated in time from initial examination, however, the statement of identity does not support an opinion or healing activity of the doctor and therefore should not be received.

In an investigative, rather than a treatment, posture, the analysis changes markedly. The child's motivation likely does not operate here in a different way than it does when talking with police officers or protective workers, whose statements are not received because of their interviewing skill, no matter how superb it may be. From the expert's perspective, many of the statements may

is the maintenance of an adversarial, as opposed to an inquisitorial, system. See Rogers v. Richmond, 365 U.S. 534, 541 (1961) (asserting with respect to interrogation of the accused that "[o]urs is an accusatorial and not an inquisitorial system-a system in which the State must establish guilt by evidence independently and freely secured and may not by coercion prove its charge against an accused out of his mouth"). Without restraint, evidence created by "second opinions," largely or totally separated from treatment, can present a similar danger.

244. The facts in United States v. Tome fit this fact pattern. Dr. Spiegel interviewed the child to give a second opinion as to whether abuse occurred approximately a year after other doctors had examined and treated the child and approximately two years after the abuse. See Tome, 3 F.3d 342, 346 (10th Cir. 1993), on remand, 61 F.3d 1446, 1450 (10th Cir. 1995). In ruling that the statements made to Dr. Spiegel were admissible, the court noted that her testimony did not include any hearsay statement identifying the perpetrator. Tome, 61 F.3d at 1450 . Thus, the most problematic case was neither presented to nor approved by the court. But see Kennedy v. State, 839 P.2d 667, 669 (Okla. Crim. App. 1992) (admitting a statement identifying the perpetrator and describing his abuse made to a pediatrician asked to give "a second medical evaluation to further delineate medical findings" several weeks after the abuse was first brought to the attention of the Department of Social Services). 
be relevant to some opinion the expert will form, but the expert will still not be permitted to give an opinion as to identity. Allowing testimony to what the expert was told because the statements would be received to support an expert opinion is not a valid justification; admission also cannot be justified because the statement relates to the child's treatment. Therefore, no theory supports admissibility. Moreover, the purposes of the interviews from the expert's perspective likely translate into environmental differences in the interview that should generally affect the perception of the child and thereby provide feedback to the child's motivation, even when it cannot be directly demonstrated. ${ }^{245}$

Thus, a basic dichotomy exists between examination and investigative interviews. ${ }^{246}$ Virtually all statements made during the immediate treatment of the child should be admissible under the medical examination exception, whether supported by explicit showings of selfish treatment motivation, a multi-factored analysis, or simply the treatment environment. Indeed, the only reason to exclude such statements is the demonstration of a strong factor negating trustworthiness. After primary medical care is completed, ${ }^{247}$ however, statements should be admitted only after either an ad hoc determination of trustworthiness under a catchall exception, or under the medical examination exception supported by a showing that the child appreciated a treatment purpose or a multi-factored analysis. If the statement was not made during initial treatment, the medical examination exception, without more, should not be the basis of admission.

The dichotomy may also dovetail with the appropriate use of videotaping. While perhaps not easily fitting into a treatment setting, videotaping is both feasible and appropriate for investigative interviews. In the latter situation, videotaping may provide a basis for admission, where factors, such as the child-like language used in combination with precocious knowledge of sexual functioning, support trustworthiness, and, where we have direct evidence not degraded by the effects of human memory, that the questioning technique was not directive and/or leading so as to undercut the reliability established by the character and content of the child's statement. ${ }^{248}$

245. Professors Mueller and Kirkpatrick suggest a way to define hearsay that would admit statements made to accomplish purposes in addition to merely communicating information, which they distinguish from ordinary hearsay in having "performative aspects." 4 MUELLER \& KIRKPATRICK, supra note $28, \S 391$, at 101-02. In some circumstances, such a definition might lend support to receiving statements made in initial stages of medical assessment of an apparent child sexual abuse victim. Professors Mueller and Kirkpatrick have indicated concern about special units established in emergency rooms, however, which they see as problematic because they are explicitly designed to generate admissible evidence. See id. $\S 442$ at 464-65.

246. This dichotomy is different than the one suggested by DeSarbo between interviewers with ongoing relationships to treat psychological maladies, which she argues should be inadmissible, and interviews with skilled investigators, which should be potentially admissible under an ad hoc test. See DeSarbo, supra note 95, at 309-14.

247. See State v. Hinnant, 523 S.E.2d 663, 670-71 (N.C. 2000) (construing the requirement of "medical pertinency" by stating that "[i]f the declarant is no longer in need of immediate medical attention, the motivation to speak truthfully is no longer present," and excluding a statement made to a clinical psychologist two weeks after the initial medical treatment).

248. Professor McGough has proposed to receive recorded videotaped statements of children made under specified conditions that help to ensure trustworthiness under the general theory of the excep- 
VI

\section{CONCLUSIONS AND RECOMMENDATIONS}

If the Supreme Court were to look at the country's experience as it did in Lilly to give guidance to the existence of consensus on a "firmly rooted" hearsay exception, it is questionable whether consensus would exist as to statements identifying the perpetrator of abuse. ${ }^{249}$ Courts disagree sharply whether such potentially accusatory statements made during an investigative interview, even when conducted by a doctor, can be received under the medical examination exception. Indeed, if what is required is consensus rather than majority view, that consensus is that, in criminal cases, statements identifying the abuser do not fit within the "medical examination exception." Rather, to be admissible, they must either satisfy a "medical treatment" exception or demonstrate a modicum of trustworthiness through a specific examination of the declarant's motivation or the circumstances surrounding the making of the statement. This reform could be accomplished by revising the rule to require a selfish treatment interest in all instances ${ }^{250}$ or through more modest but also somewhat more complicated remedies summarized below. ${ }^{251}$

A complicated formula for uniform admissibility in all jurisdictions would constitute an unreasonable proposal. It would also be unwarranted in doctrine and unsupported by national experience. Doctrine and our experience, however, are sufficient to yield several clear lines of demarcation guiding decisions on admissibility. Three principles should guide this determination.

tion for past recollection. See MCGough, supra note 60, at 274-76. Her approach and that proposed here have much in common.

249. The disputed class of hearsay statements appears relatively specific and, indeed, arguably too narrow for Supreme Court concern or special treatment. This troubling class of statements identifying the perpetrator, however, is quite analogous to the troubling category of statements against penal interest inculpating another that the Court condemned in Lilly.

250. Regardless of the reform model used, the effort to guarantee trustworthiness can be thwarted if courts do not insist upon a real showing of treatment motivation and instead permit the requirement to be satisfied by a pro forma showing that the medical personnel alerted the child to the treatment significance of the interview. See infra note 253 and accompanying text.

251. I turn now to a very specific type of statement where the application of the exception is problematic. Statements by individuals other than the victim regarding the abuser's identity are only rarely encountered, but a few courts have admitted such statements. Their admission should not be allowed. Receiving such statements can only be justified through multiple extensions of the exception's rationale. Statements of identity may be perceived by the patient as relevant to a treatment interest, but that link is always uncertain. Such statements are even more tenuously connected to any valid theory when offered to support an expert's opinion or because the expert considers them pertinent to the protection of the child. When offered by another party, their justification under the selfish treatment interest is conceptually possible where the person making the statement has a close affinity to the child, as would a mother. In those circumstances, however, the statements are almost always highly accusatory, which counters the trustworthiness flowing from the interest in the child's well-being. Their place in supporting the expert's opinion, which cannot be rendered in court, is clearly not adequate justification. See, e.g., Lovejoy v. United States, 92 F.3d 628, 631 (8th Cir. 1996) (admitting statements made by a mother describing observations of the defendant and the victim because of concern shown by the mother for the welfare of her child and consistency of the statement with promoting treatment); United States v. Yazzie, 59 F.3d 807, 812-13 (9th Cir. 1995) (admitting the statement of a mother identifying the child's stepfather as the abuser because the mother stated her concern for the health of her child and exhibited that concern through her demeanor). 
First, statements, including those identifying the perpetrator, made by children to physicians and those assisting them shortly after discovering the abuse should be admissible. Immediacy of examination and a clear connection to the possibility of treatment should establish the outer limits of statements admitted under the diagnosis prong of the exception. That rationale for admission should be categorically denied to statements made subsequent to an initial medical examination, even when made to doctors, because the expert is likely consulted for a second opinion and preparation for prosecution. Such delayed statements should be admitted only upon a specific showing that the child perceived the statements as contributing to effective treatment or after an evaluation of the totality of the circumstances as done under the catchall exception. Under a multi-factored test, if the auditor's motivation is of one preparing for litigation, a strong presumption against admissibility should exist.

Second, statements should generally be receivable if made during the course of actual treatment. A particularly difficult class of cases involve long-term psychological therapy, where distinguishing between therapy and investigative interviews will sometimes be difficult. The likelihood that the child believes the conversations benefit health and the likelihood that the interviewer is not tainted by prosecutorial interests both grow as time passes in the interview process. ${ }^{252}$ Generally, only in an ongoing treatment setting should statements to psychologists, psychiatrists, and social workers be admissible.

Third, courts must avoid providing a "cookie cutter" method of transforming investigative statements into those made for treatment by mechanically assuming that the child's motivation changes when the auditor informs the child that answering questions will help with treatment. ${ }^{253}$ If that formula always works, the integrity of the entire protective system may always be easily circumvented, and any claim that trustworthiness is actually being guaranteed disappears. Courts must look realistically at the situation and determine in context whether the statement by the auditor regarding the usefulness of the statement to treatment would produce a real shift in the child's motivation. Where the circumstances indicate that treatment would reasonably be anticipated, informing the child of the importance of the statement to treatment should be assumed to have an effect. When circumstances suggest little likelihood of connection to treatment and instead indicate an investigative environment, however, the statement of the auditor should be insufficient.

252. My conclusion is similar to that of Professor Capowski, but my reasoning is different. See Capowski, supra note 52. Not all types of "therapy" should qualify as a basis for receiving statements. Some types of therapeutic environments are potentially so supportive as to be suggestive of abuse. Thus, as to some types of therapies, DeSarbo's argument has validity and should render the statements inadmissible. See DeSarbo, supra note 95, at 309-14.

253. The statement to the child about the medical purpose of the interview should be viewed in its realistic context. That such a statement was made to the child should always be a factor supporting the existence of a selfish treatment interest. It should not, however, always be effective as a matter of fact. If it were, ostensibly requiring a selfish treatment interest would, in reality, provide no guarantees of trustworthiness. 